\title{
Evolución jurisprudencial del delito de maltrato o crueldad animal en Chile
}

\author{
Rodrigo Antonio Mella Pérez
}

Relator. Poder Judicial de la República de Chile

Recepción: Mayo 2018

Aceptación: Junio 2018

\section{Resumen}

El presente trabajo expone y sistematiza las conclusiones alcanzadas por tribunales con competencia criminal en Chile cuando se han visto enfrentados a juzgar hechos calificados como constitutivos de maltrato o crueldad en contra de animales no humanos, evidenciando la relación entre tales decisiones y el tenor de los enunciados típicos contemplados en la ley y las directrices formuladas por la doctrina penal.

Palabras Clave: maltrato animal, abuso animal, crueldad animal, evolución, jurisprudencia, Chile.

\section{Abstract. The judicial evolution of animal abuse in Chile}

This paper exposes and systematizes the conclusions reached by Chileans criminal courts when they have been faced with judgments about facts that can be considered to be constitutive of mistreatment or cruelty against nonhuman animals, evidencing the relationship between such decisions and the provisions contemplated in the law and the guidelines formulated by the authority.

Key words: animal abuse, animal mistreatment, animal cruelty, evolution, judicial decisions, Chile. 


\section{SUMARIO}

1. Aproximación al problema

2. Los animales no humanos en el derecho internacional

3. Los animales no humanos en el derecho chileno

4. Análisis doctrinario del delito de maltrato animal

5. Evolución jurisprudencial del delito de maltrato animal

6. Conclusiones

Bibliografía

\section{APROXIMACIÓN AL PROBLEMA}

"La profecías de lo que los tribunales harán de hecho y no otra cosa con más pretensiones, tal es lo que entiendo por derecho” postuló un destacado jurista norteamericano en el ocaso del siglo XIX ${ }^{1}$. Esta afirmación puede ser considerada como ápice de una corriente ius filosófica pragmática que sería conocida como realismo jurídico conductista. Si bien es cierto sus planteamientos se encuadran en el contexto del common law anglosajón, donde el precedente jurisprudencial es considerado como una fuente directa e inmediata del derecho, al resultar vinculante en la resolución de casos posteriores, es evidente que aun en los sistemas jurídicos continentales las decisiones de los tribunales de justicia poseen una amplia utilidad debido a su función interpretadora, creadora, integradora, adaptadora y promotora de uniformidad del Derecho.

Por ello, a través de la presente investigación se pretende exponer, sistematizar y analizar el desarrollo que ha tenido el razonamiento judicial cuando tribunales se han visto enfrentados a aplicar las figuras típicas que castigan conductas constitutivas de maltrato o crueldad animal conforme a la ley chilena, enfatizando la forma como tales decisiones han dotado de contenido al enunciado típico y han recogido las propuestas planteadas por la doctrina penal.

Cumplir con dicho objetivo posee una utilidad evidente, pues las conclusiones a que se arribe como corolario de esta investigación servirán como guía para los operadores jurídicos que busquen argumentos ante situaciones similares en el futuro. Desde un punto de vista metodológico, la labor investigativa que aquí se desarrollará utilizará tres herramientas. En primer lugar, se expondrá el marco regulatorio atinente a los animales no humanos, tanto en el derecho internacional como en el ordenamiento jurídico doméstico chileno, con especial énfasis en la evolución del tratamiento penal que la Ley ha dado a los actos de maltrato o crueldad. Luego, se analizarán las consideraciones doctrinarias pertinentes respecto de la figura típica de maltrato o crueldad animal actualmente vigente. Finalmente, se examinará crítica y detalladamente los casos más relevantes que han sido sometidos a conocimiento de los tribunales con competencia penal en Chile, develando la forma como las decisiones judiciales han entendido la figura típica.

\section{LOS ANIMALES NO HUMANOS EN EL DERECHO INTERNACIONAL}

Para los fines de este trabajo, este apartado se centrará en el análisis del instrumento internacional más importante en materia de protección a los animales no humanos,

\footnotetext{
${ }^{1}$ Holmes, O. W. (1897). The Path of the Law. Harvard Law Review 457, pág. 9. 
consistente en la "Declaración Universal de los Derechos de los Animales” (en adelante "la Declaración”), sin desconocer la existencia de profusa regulación internacional en materias específicas, principalmente destinadas a salvaguardar especies vulnerables o al tratamiento de animales cuya explotación pude tener significación económica, tópicos que escapan al objetivo que aquí se busca satisfacer.

Adoptada por la Liga Internacional de los Derechos Humanos del Animal y las ligas nacionales afiliadas, con motivo de la celebración de la Tercera Reunión Internacional sobre los Derechos del Animal (Londres, 21-23 de septiembre de 1977), la Declaración fue proclamada el 15 de octubre de 1978 por la Liga Internacional y las personas físicas y morales que se asociaron al acto. Se proclamó en 1978. Sin embargo, es una mera declaración de intenciones, que no tiene vinculaciones legales reales. La Declaración postula una visión del animal no humano como sujeto de derechos, los que históricamente han sido despreciados y desconocidos por el hombre, asimilando su respeto a aquel que merecen los seres humanos entre ellos mismos.

En cuanto a su contenido concreto, este instrumento comienza proclamando la igualdad ante la vida y derecho de existencia de todos los animales, evidenciando una perspectiva anti-especista, lo que implica rechazar el sufrimiento animal al igual que el sufrimiento humano ${ }^{2}$. En el mismo sentido, se proscriben los malos tratos y actos crueles, definiendo como tal también al abandono, e instando al ser humano al cuidado, atención y protección del resto de los animales. Por otro lado, en caso de ser necesario provocar la muerte de un animal, la Declaración ordena que se utilicen medios instantáneos e indoloros, prohibiendo la experimentación animal que conlleve sufrimiento físico o psicológico, junto con establecer otros derechos y garantías no relacionados con este estudio.

Ahora bien, la validez y aplicabilidad de la Declaración como fuente del derecho interno chileno es un asunto discutido en doctrina. Por un lado, se ha sostenido que este instrumento no puede entenderse como parte del ordenamiento jurídico nacional pues Chile no ha adherido a él, y que, aun en caso de llegar a la conclusión contraria, de todos modos no podría considerarse a los animales no humanos como sujetos de derecho debido a su ausencia de representación y patrimonio ${ }^{3}$. En un sentido distinto, se propone que toda declaración internacional, en especial las que emanan de la Organización de las Naciones Unidas y su Asamblea, deben ser consideradas como principio general del derecho, no obstante su ausencia de ratificación o sanción formal ${ }^{4}$.

En cualquier caso, la Declaración de los Derechos de los Animales constituye un antecedente inmediato del proyecto de "Ley de Protección de Animales" de 1995, que luego derivó en el Boletín Nº1721-12, y concluyó en la estructuración de la Ley 20.380, cuyo contenido se analizará más adelante, por lo que, al menos, la Declaración debe ser considerada como una fuente indirecta de la normativa doméstica actualmente vigente ${ }^{5}$.

\section{LOS ANIMALES NO HUMANOS EN EL DERECHO CHILENO}

Es posible sostener que la referencia a los animales en el derecho chileno es anterior, incluso, a las primeras leyes propiamente domésticas. Las "Siete Partidas", cuerpo normativo que rigió en los albores de la república ante la ausencia de un ordenamiento jurídico interno, comprendía a los animales "con sentidos" como sujetos de derecho natural ${ }^{6}$, ordenando "al pueblo”, acto seguido, el "apoderarse por fuerza de la tierra” ejemplificando tal mandato con

\footnotetext{
2 Singer, P. (1999). Liberación Animal. Madrid: Trotta, pág. 44

${ }^{3}$ De Carvalho González, E. (2016). La comisión por omisión en el delito de maltrato o crueldad animal. Santiago de Chile: Actividad formativa para optar al grado de Magister en Derecho por la Universidad de Chile, pág. 49

${ }^{4}$ Ibidem.

${ }^{5}$ De Carvalho González, E. (2016). La comisión por omisión en el delito de maltrato o crueldad animal (...), opus. cit., pág. 53

${ }^{6}$ Ley No2, Título I, Primera Partida.
} 
el matar a "los animales bravos y fuertes"7.

Una vez logrado el establecimiento de las incipientes instituciones republicanas, los animales no humanos siguieron siendo objeto de preocupación legislativa, lo que se tradujo en su inclusión, por diversas razones o motivos, en los principales cuerpos normativos codificados, algunos de los cuales se encuentran vigentes hasta hoy.

\subsection{Animales no humanos en el Derecho Privado}

En vigor desde 1854, el Código Civil chileno considera sistemáticamente a los animales no humanos como cosas u objetos susceptibles de apropiación humana, confiriendo atributos a quien sea titular del dominio u otro derecho real sobre ellos. Sin embargo, este estatuto también reconoce en los animales no humanos ciertas particularidades que los diferencia del resto de las cosas, como por ejemplo su relación con actividades productivas, su capacidad de movimiento autónomo y su especial aptitud o potencial para producir daño a terceros o al patrimonio ajeno.

La primera de aquellas características se manifiesta en el artículo 646 del mencionado Código, regla que, refiriéndose a la accesión como modo de adquirir los frutos de una cosa, resuelve que "las pieles, lana, astas, leche, cría, y demás productos de los animales, pertenecen al dueño de éstos" ${ }^{8}$. Como se aprecia, aquí expresamente se afirma que los animales no humanos y sus crías pueden ser objeto de apropiación humana, en tanto se asume que ellos producen ciertos frutos cuya propiedad accede al dueño del animal. Asimismo, la relación entre los animales y las actividades productivas humanas se contempla en el artículo 570 del Código, norma que "reputa inmuebles aunque por su naturaleza no lo sean" a "los animales actualmente destinados al cultivo o beneficio de una finca” y a aquellos que "se guardan en conejeras, pajareras, estanques, o colmenas" ${ }^{9}$. Por último, dada la importancia económica que poseían en un contexto histórico, se regula especialmente en los artículos 620 y 621 la relación entre el dueño y las palomas y abejas que han abandonado su colmena o palomar, respectivamente ${ }^{10}$.

El segundo atributo especial, consistente en la capacidad de movimiento autónomo, se desprende del tenor del artículo 567 del Código Civil, norma que define como cosas muebles a aquellas que "pueden transportarse de un lugar a otro, sea moviéndose ellas a sí mismas, como los animales (que por eso se llaman semovientes), sea que sólo se muevan por una fuerza externa, como las cosas inanimadas” ${ }^{11}$. Incluso más, cuando en su artículo 608 distingue entre animales bravíos o salvajes, domésticos y domesticados, este cuerpo normativo asume que los animales no humanos cuentan con cierta capacidad volitiva, al incluir en la última categoría (domesticados) a aquellos animales bravíos que "reconocen en cierto modo el imperio del hombre”, asimilándolos al régimen aplicable a los animales domésticos "mientras conservan la costumbre de volver al amparo o dependencia del hombre" 12 .

Finalmente, la aptitud o potencial de los animales no humanos para producir perjuicio a terceros o al patrimonio ajeno queda de manifiesto en lo dispuesto en los artículos 2326 y 2327 del Código Civil ${ }^{13}$, donde se imputa la responsabilidad por los daños causados por ellos a su dueño, con especial severidad en el caso de los animales “fieros” pues, ante el detrimento causado por dichas especies, se priva a su tenedor de la posibilidad de alegar la inevitabilidad del hecho dañoso.

\footnotetext{
${ }^{7}$ Ley N ${ }^{\circ} 7$, Título XX, Segunda Partida.

${ }^{8}$ https://www.leychile.cl/Navegar?idNorma=172986

${ }^{9}$ Ibidem.

${ }^{10}$ Ibidem.

${ }^{11}$ Ibidem.

12 Ibidem.

13 Ibidem.
} 
Como se puede apreciar, si bien el derecho privado chileno, en especial el derecho civil, categoriza aun a los animales no humanos como cosas susceptibles de dominio u apropiación humana, lo cierto es que implícitamente ve en ellos ciertas características distintivas respecto del resto de los miembros tal categoría, distinción que, como se verá a continuación, transciende a esta disciplina jurídica e impregna otras ramas, como ocurre en el caso del derecho penal.

\subsection{Animales no humanos en el Derecho Penal}

En aproximación al objeto del presente estudio, corresponde ahora abocarse al estudio del tratamiento que el derecho penal chileno ha otorgado a los animales no humanos. Para ello se expondrá, en primer orden, la evolución histórica de la normativa específica para, luego, desglosar los alcances doctrinarios que la figura típica actualmente vigente conlleva.

\subsubsection{En el Código Penal de 1874}

Al igual que el Código Civil, ya en su texto original el Código Penal chileno otorgaba a los animales un tratamiento especial, adelantándose incluso a su símil español ${ }^{14}$. Así, en el artículo 496 №35 catalogaba como falta, asociado a un castigo de 41 a 60 días de prisión conmutable por multa, a quien "se hiciere culpable de actos de crueldad o maltrato excesivo hacia los animales" 15 .

Cabe destacar que la conducta descrita en la norma permanece inalterada hasta el día de hoy, al castigar "actos de crueldad o maltrato" ejecutados en contra de animales ajenos al ser humano, sin ulterior distinción expresa entre especies. Acto seguido, de acuerdo a la norma, para la configuración de la faz objetiva del tipo era necesaria también la concurrencia de un elemento cuantitativo: La crueldad o el maltrato debía ser "excesivo", lo que, a contrario sensu, implica cierto nivel de tolerancia ante algunas conductas que pudieren causar sufrimiento a animales no humanos, siempre que ellas no alcanzaren de dicha intensidad.

A pesar que a partir de la norma en cuestión se suscitan variados e interesantes problemas interpretativos, esta figura no fue objeto de mayor análisis por la doctrina y jurisprudencia de su tiempo, pues, dada su baja penalidad, no derivó en actos de persecución relevantes por parte de los organismos encargados de dirigir la investigación criminal. Por ello, interrogantes tales como la incidencia de la expresión "culpable” en la configuración del tipo subjetivo, o el verdadero sentido y alcance de las voces "maltrato", "crueldad” o "excesivo" no encontraron oportuna respuesta.

En razón de lo anterior, es posible inferir que, si bien esta antigua norma promovía la proscripción del maltrato o crueldad excesivo reconociendo en los animales capacidad de sufrimiento, asume como posibilidad la ejecución de actos aptos para producir dichas consecuencias en su contra, siempre que ellos resulten necesarios para su control o aprovechamiento, lo que es perfectamente concordante con la visión que sobre los animales poseía el derecho civil, tal como se ha dicho, al entenderlos como un especial tipo de cosa cuya principal característica consiste en coadyuvar al hombre en el desarrollo de actividades económicas.

\subsubsection{En la Ley 18.859 de 1989}

Debieron pasar más de 120 años para que, concretamente el 29 de noviembre de 1989, viere la luz del Derecho una nueva figura típica que, guardando similitudes con la original, confiere a los animales no humanos una protección mucho más intensa.

\footnotetext{
${ }^{14}$ Laimene Lelanchon, L. Leyes contra el maltato animal en Francia y España, en dA 5/1 (2014) pág. 3 http://revistes.uab.cat/da/article/view/v5-n1-laimene/112

${ }^{15}$ https://www.leychile.cl/Navegar?idNorma=1984\&tipoVersion=0 
En efecto, la Ley $\mathrm{N}^{\circ} 18.859$ deroga la falta estudiada en el acápite precedente, introduciendo el artículo 291 bis al Código Penal, norma que primitivamente prescribía: “El que cometiere actos de maltrato o crueldad con animales, será castigado con la pena de presidio menor en su grado mínimo y multa de uno a diez ingresos mínimos mensuales o sólo a esta última” 16 .

Así, manteniendo la conducta típica de la figura anterior, se asigna a su ejecución un castigo más severo, propio de simples delitos, como lo es el presidio entre 61 y 540 días, además de la pena conjunta o alternativa de multa. En segundo lugar, la nueva figura no contempla la exigencia cuantitativa que debía concurrir para la configuración de la falta que le precedía, no requiriéndose, ahora, que dicha crueldad o el maltrato fuese "excesiva".

La finalidad de la ley queda de manifiesto en su propio título, el cual anuncia la modificación del Código Penal "en lo relativo a la protección animal”, mientras que de la historia fidedigna de su establecimiento se desprende, con claridad, que para el legislador resulta insuficiente la protección de la integridad animal bajo la figura del delito de daños, pues se trata de individuos sui generis que no pueden ser equiparados a cosas inanimadas al estar dotados de sensibilidad, debiendo ser considerados, los animales, no como cosas sino como criaturas. Por otro lado, la nueva figura también se ha sustentado en criterios de política criminal, pues el legislador entiende que "los actos de crueldad con los animales predisponen al hombre a la violencia"17.

Como conclusión, se postula que la nueva norma constituye un avance, pero restringido únicamente al tratamiento penal de conductas constitutivas de maltrato o crueldad, sin que se contemplen medidas efectivas de prevención distintas a la mera amenaza de castigo, el que, si bien ve incrementada su intensidad sigue siendo exiguo, al mantener la pena alterna de multa en perjuicio de la sanción privativa de libertad. No deja de llamar la atención, finalmente, que en la historia de su establecimiento se exponga una visión marcadamente antropocentrista, justificando la validez moral de la nueva norma en criterios preventivos respecto del mal que el autor de maltrato o crueldad animal pueda, potencialmente, provocar a otros seres humanos, entendiendo a la protección de los animales no humanos como un verdadero adelanto punitivo frente a la comisión de futuros delitos contra las personas.

\subsubsection{En la Ley 20.380 de 2009}

Constitutiva de un avance mayor en la protección de los animales no humanos, la ley 20.380, vigente desde su publicación el 3 de octubre de 2009, posee como objetivo explícito, según su artículo $1^{\circ}$, el "conocer, proteger y respetar a los animales, como seres vivos y parte de la naturaleza, con el fin de darles un trato adecuado y evitarles sufrimientos innecesarios”18, ordenando, a renglón seguido, su división según especies entre domésticos y silvestres, asunto que entrega a la potestad reglamentaria del Presidente de la República.

En cuanto a su contenido, esta ley apunta a regular un espectro amplio, estableciendo reglas sobre educación en su Título II, sobre experimentación con animales vivos en su Título IV, sobre el beneficio y sacrificio en su Título V, sobre transporte en su artículo $4^{\circ}$, y sobre la tenencia de animales para la ejecución de funciones puntuales, tales como circos, zoológicos, laboratorios veterinarios, establecimientos de producción industrial, locales de compraventa de animales, lugares de adiestramiento, concurso y hospedaje, entre otros, en su artículo $5^{\circ}$.

Respecto a la directa protección animal, el artículo $3^{\circ}$ de este cuerpo normativo impone a toda persona que ejerza la tenencia de un animal doméstico la obligación de

\footnotetext{
${ }^{16}$ https://www.leychile.cl/Navegar?idNorma=30234

${ }^{17}$ De Carvalho González, E. (2016). La comisión por omisión en el delito de maltrato o crueldad animal (...), opus cit., págs. 27-29

${ }^{18} \mathrm{https}: / / w w w . l e y c h i l e . c l / N a v e g a r ? i d N o r m a=1006858$
} 
"cuidarlo y proporcionarle alimento y albergue adecuados, de acuerdo, al menos, a las necesidades mínimas de cada especie y categoría y a los antecedentes aportados por la ciencia y la experiencia”, mientras que, respecto de los animales silvestres, prescribe que su libertad de movimiento "no debe ser restringida de manera innecesaria, especialmente si ello les ocasionare sufrimiento y alteración de su normal desarrollo" ${ }^{19}$.

Como se logra apreciar, las exigencias introducidas por la norma antes citada pueden ser calificadas como vagas, imprecisas o etéreas, por lo que difícilmente podrían dar origen a la imposición de un castigo ante su incumplimiento dado lo abstracto de su supuesto de hecho, a pesar que el artículo $13^{\circ}$ contempla la pena de multa ante su contravención ${ }^{20}$.

Ya en lo atinente a la presente investigación, el artículo 18 de la ley en análisis reemplaza el artículo 291 bis del Código Penal, quedando su enunciado compuesto de la siguiente manera: "El que cometiere actos de maltrato o crueldad con animales será castigado con la pena de presidio menor en sus grados mínimo a medio y multa de dos a treinta unidades tributarias mensuales, o sólo con esta última” ${ }^{21}$.

A partir de un simple ejercicio comparativo, se concluye que el supuesto de hecho, consistente en la ejecución de actos de "maltrato o crueldad con animales", se mantiene inalterado, limitándose la norma a incrementar el castigo posible a imponer, el que muta desde un máximo de 540 días de presidio, a 3 años de la misma sanción, manteniendo su mínimo en 61 días. En cuanto a la multa, esta curiosamente disminuye, desde un máximo equivalente a 2.700 .000 pesos chilenos (3.500€ aproximadamente) a un tope de 1.403 .610 pesos chilenos (1800€ aproximadamente).

Vale aquí formular la misma crítica que afectaba a la norma anterior, al establecerse la posibilidad de aplicación alternativa de una multa cuantitativamente disminuida, en desmedro de la pena privativa de libertad.

Una innovación importante introducida por la ley, consiste en la facultad conferida al juez, en su artículo $12^{\circ}$, para ordenar, en caso de actos de maltrato o crueldad, "que los animales afectados sean retirados del poder de quien los tenga a su cargo para ser colocados al cuidado de una persona natural o jurídica que se designe al efecto", y/o "disponer el tratamiento veterinario que corresponda, en caso de encontrarse los animales afectados heridos o con deterioro de su salud” ${ }^{22}$, medidas que se podrán llevar a efecto de manera provisional durante la instrucción, y deberán ser solventadas por el imputado.

No obstante reconocer la originalidad de tales medidas reparatorias, las que por regla general son ajenas al derecho penal chileno; de inmediato es posible identificar una serie de falencias. En primer lugar, al no haber sido incorporado este enunciado al Código Penal, su existencia ha pasado prácticamente desapercibida para los operadores jurídicos, mermando su aplicación práctica. En segundo orden, la posibilidad de "retiro" del animal maltratado pugna con el tratamiento cosificado que le otorga Derecho Civil, al no alterar su dominio pero si su tenencia, lo que podría generar conflictos que atentarían en contra de la finalidad eminentemente protectora de la medida. En tercer lugar, Chile carece, hasta el día de hoy, de registros de personas naturales o jurídicas que se dediquen al cuidado de animales maltratados, circunstancia que dificulta su implementación. Finalmente, el hecho de prescribir que las medidas reparatorias sean solventadas por el imputado de maltrato o crueldad importa un total desentendimiento del Estado en su ejecución, situación inadmisible si se considera que se trata de procedimientos de urgencia, cuya dilación podría implicar el incremento del daño para el animal maltratado.

En cualquier caso, debe ser valorado el hecho que, a través de esta ley, la protección de los intereses no humanos se haya extendido a sectores a los que la regulación anterior no alcanzaba, mientras que su aporte fundamental consiste en el cambio de perspectiva o

\footnotetext{
${ }^{19}$ Ibidem.

${ }^{20}$ Ibidem.

${ }^{21}$ Ibidem.

${ }^{22}$ Ibidem.
} 
enfoque de la protección, desde una visión marcadamente antropocéntrica, poniendo ahora el foco sobre el animal no humano, en su calidad de ser sintiente, buscando evitar o proscribir el sufrimiento o dolor innecesario.

\subsubsection{En la LEY 21.020 DE 2017}

En vigencia desde el 2 de agosto de 2017, la ley sobre "tenencia responsable de mascotas y animales de compañía" 23 forma parte del ordenamiento jurídico chileno introduciendo ciertos estándares mínimos que, desde hace ya bastante tiempo, son exigibles en países desarrollados.

Su objetivo primordial, según se desprende del tenor de su articulado, es regular las obligaciones y derechos de las personas responsables de animales domésticos, así como proteger la salud y bienestar de estos últimos mediante la imposición de variadas exigencias a su tenedor.

Para este efecto, la ley divide a los animales domésticos en dos grandes grupos: Las mascotas o animales de compañía y los animales potencialmente peligrosos, estableciendo regímenes diversos para las especies pertenecientes a cada una de estas categorías. Tal distinción es encomendada nuevamente por la ley a la potestad reglamentaria, fijando tres parámetros en función de los cuales un animal determinado puede ser considerado como "potencialmente peligroso" 24 , a saber: La pertenencia a una determinada raza, sus características físicas y su conducta. De ser incluido en esta clasificación, el dueño o poseedor del animal responderá de los daños que este produzca tal como si fuera un animal “fiero”, según los parámetros señalados en el Código Civil chileno y que han sido expuestos con antelación.

Luego, este cuerpo normativo consagra los parámetros generales de lo que denomina “estrategia de protección y control de la población animal”25, en lo que constituye la primera política pública de este tipo a nivel nacional. Tal estrategia se basa en dos grandes principios: La colaboración con personas jurídicas privadas sin fines de lucro que pudieren establecer centros de mantención temporal de mascotas o animales de compañía, y la proscripción de la eutanasia como mecanismo de control de población.

Otra innovación contemplada en la ley, consiste en la creación de un sistema de registro e identificación de mascotas o animales de compañía ${ }^{26}$. En cuanto al registro, este deberá contemplar, a lo menos, la identidad y domicilio del dueño del animal; el nombre, género, especie, color y raza del animal; y el número que se asigne al mismo para su debida identificación. Respecto de la ejecución de la identificación del animal, ella deberá ser realizada mediante la utilización de "un dispositivo permanente e indeleble, de modo que permita relacionarlos con el responsable de tales mascotas o animales de compañía”27.

Ya en cuanto a su contenido penal propiamente tal, el artículo 11 de la ley prohíbe el adiestramiento de mascotas o animales de compañía, cuando éste vaya dirigido a acrecentar o reforzar su agresividad, sancionando dicha conducta con la imposición de una multa, unida a una nueva pena accesoria consistente en la "inhabilidad absoluta perpetua para la tenencia de animales" 28 .

También desde una perspectiva punitiva, se prohíbe toda pelea de mascotas o animales de compañía, incluidos los animales potencialmente peligrosos, cuando ella sea organizada como espectáculo, considerando como maltrato o crueldad tal acto para efecto de

\footnotetext{
${ }^{23}$ https://www.leychile.cl/Navegar?idNorma=1106037

${ }^{24}$ Ibidem.

${ }^{25}$ Ibidem.

${ }^{26}$ Ibidem.

${ }^{27}$ Ibidem.

${ }^{28}$ Ibidem.
} 
su castigo, sancionando con pena de multa la promoción o difusión de estas actividades ${ }^{29}$.

Otra asimilación a maltrato o crueldad se establece en el artículo 12 de la ley, norma que soluciona el que, como se verá, constituía uno de los más intensos problemas interpretativos que proponía la redacción primitiva del artículo 291 bis, como lo es el régimen aplicable al abandono de animales no humanos, o la posibilidad de comisión por omisión de actos de maltrato o crueldad. La nueva regla indica directamente que "el abandono de animales será considerado maltrato y crueldad animal y será sancionado de acuerdo a lo establecido en el artículo 291 bis del Código Penal”30.

En el ámbito procesal penal, este cuerpo normativo establece la posibilidad que las "organizaciones promotoras de la tenencia responsable de mascotas o animales de compañía" actúen como querellantes en causas criminales donde se persiga delitos de maltrato o crueldad animal $^{31}$. La introducción de esta modificación no deja de llamar la atención, pues la querella, entendida como la intromisión del interés particular en la persecución penal, es considerada como una institución procesal indeseable en el sistema acusatorio actualmente en vigencia y, por regla general, se limita a casos excepcionales, concediéndose tal facultad primordialmente a la víctima. Es precisamente en este punto donde se revela su justificación, pues dentro de un ordenamiento jurídico que histórica y contemporáneamente ha cosificado a los animales no humanos, se tiende a calificar como víctima de los actos de maltrato o crueldad a su dueño, siendo el mismo dueño quien muchas veces posee la calidad de ejecutor de tales indeseadas conductas, surgiendo la necesidad que otro u otros pasen a ejercer la representación en juicio del interés animal, consistente en evitar el dolor o su reiteración.

Respecto a la figura típica de maltrato o crueldad, la nueva ley mantiene inalterado el tenor del artículo 291 bis, pero agrega dos incisos a dicha regla y, de la misma manera, introduce el artículo 291 ter al Código Penal ${ }^{32}$.

El inciso segundo del artículo 291 bis dice: “Si como resultado de una acción u omisión se causare al animal daño, la pena será presidio menor en sus grados mínimo a medio y multa de diez a treinta unidades tributarias mensuales, además de la accesoria de inhabilidad absoluta perpetua para la tenencia de cualquier tipo de animales”. A su vez, el inciso tercero de dicha norma prescribe: "Si como resultado de las referidas acción u omisión se causaren lesiones que menoscaben gravemente la integridad física o provocaren la muerte del animal se impondrá la pena de presidio menor en su grado medio y multa de veinte a treinta unidades tributarias mensuales, además de la accesoria de inhabilidad absoluta perpetua para la tenencia de animales" ${ }^{33}$. Finalmente, el nuevo artículo 291 ter indica: "Para los efectos del artículo anterior se entenderá por acto de maltrato o crueldad con animales toda acción u omisión, ocasional o reiterada, que injustificadamente causare daño, dolor o sufrimiento al animal”34.

Como se aprecia, el conjunto de normas contenido en esta ley posee virtudes y defectos. Dentro de sus virtudes podemos mencionar el compromiso del Estado con el bienestar animal a través del establecimiento de políticas públicas de control y protección, el reconocimiento de los animales no humanos como seres poseedores de un interés jurídicamente relevante, y la solución a diversos problemas de interpretación que la norma penal de crueldad o maltrato registraba. En cuanto a sus falencias, llama la atención que la ley gira en torno a mascotas o animales de compañía, realizando reiteradas referencias a perros y gatos, especies que, si bien culturalmente son el ejemplo paradigmático de mascota, se encuentran lejos de ser las únicas que requieren protección y atención por parte de la sociedad. Asimismo, limitar el maltrato o crueldad a un delito de resultado, el que

\footnotetext{
${ }^{29}$ Ibidem.

${ }^{30}$ Ibidem.

${ }^{31}$ Ibidem.

${ }^{32}$ https://www.leychile.cl/Navegar?idNorma=1984

${ }^{33}$ Ibidem.

${ }^{34}$ Ibidem.
} 
expresamente se ha restringido al "daño, dolor o sufrimiento"35 del animal, deja fuera una serie de conductas que, sin provocar tales consecuencias, pueden ser consideradas como tanto o más indeseables que aquellas que sí lo hacen, como, por ejemplo, la explotación comercial o sexual de animales no humanos. Finalmente, en el artículo 291 ter aparece la "justificación” del resultado como causal de exención de responsabilidad penal, generando un nuevo problema interpretativo.

\section{ANÁLISIS DOCTRINARIO DEL DELITO DE MALTRATO ANIMAL}

A continuación, se examinarán ciertas consideraciones dogmáticas formuladas respecto de la figura de maltrato o crueldad animal, según el contenido objetivo y subjetivo del enunciado expuesto con antelación, para, así, determinar sus presupuestos de aplicabilidad y los límites del ejercicio del poder punitivo del Estado.

\subsection{Elementos del tipo objetivo}

Siguiendo a Roxin, el "tipo", como categoría dogmática del derecho penal fue formulado e introducido por BELING a comienzos del siglo XX, atribuyéndosele funciones sistemáticas, dogmáticas y políticocriminales. Proviniendo de la traducción literal del alemán Tatbestand o "supuesto de hecho", el tipo puede ser definido como "el compendio o conjunto de los elementos que dan como resultado saber de qué delito típicamente se trata"36. A tal conjunto de elementos se hará referencia en las líneas venideras, en relación con el delito de maltrato animal actualmente comprendido en el Código Penal chileno.

\subsubsection{Conducta}

Inalterada desde la redacción original del Código Penal chileno, la conducta base que supone la imposición del castigo consiste en la ejecución de "actos de maltrato o crueldad" 37 . Para determinar qué significa y cuál es el alcance de las expresiones "maltrato” y "crueldad”, resulta útil, en principio, acudir a su sentido natural. El verbo "maltratar" posee dos acepciones: Tratar mal a alguien y menoscabar o echar a perder ${ }^{38}$. A su turno, el adjetivo “cruel” conlleva que el acto sea insufrible, excesivo, sangriento, duro o violento ${ }^{39}$.

Ahora, utilizando un razonamiento sistemático, es dable afirmar -como se verá en detalle más adelante- que tal conducta debe poseer aptitud para causar un resultado básico: El dolor del animal en cuestión, a través de la alteración de ciertos parámetros mínimos que, para la ciencia contemporánea, configuran lo que se ha denominado "bienestar animal”, el que puede ser definido como el "estado de completa salud mental y física, donde el animal está en perfecta armonía con el ambiente que le rodea; siendo el estado en el que el individuo no tiene que enfrentarse con su entorno" ${ }^{40}$. Existe consenso en que los referidos parámetros consisten en: La ausencia de sed prolongada, el confort en relación al descanso, el confort térmico, la facilidad de movimiento, la ausencia de lesiones, la ausencia de enfermedad, la ausencia de dolor causado por conductas humanas, la expresión de un comportamiento social adecuado, la interacción adecuada entre los animales y sus cuidadores, y la ausencia de miedo en general $^{41}$.

\footnotetext{
${ }^{35}$ Ibidem.

${ }^{36}$ Roxin, C. (1997). Derecho Penal Parte General Tomo I. Madrid: Civitas. pág. 275

${ }^{37}$ https://www.leychile.cl/Navegar?idNorma=1984

${ }^{38} \mathrm{http://www.rae.es/}$

${ }^{39}$ Real Academia Española, 2017.

${ }^{40}$ Hughes, B. (1976). Preference decisions of domestic hens for wire or litter floors. Applied Animal Ethology 2, pág. 157.

${ }^{41}$ Rodríguez-Estévez, V. (2 de Julio de 2017). Zootecnia y gestión. pág. 13. Obtenido de Universidad de Córdoba: http://www.uco.es/zootecniaygestion/img/pictorex/30_16_09_Binestar_Animal_VRE.pdf
} 
A esta misma conclusión arriba la doctrina penal nacional, a través de autores que proponen que ejecutar actos de maltrato o crueldad implica "someter al animal a un trato abusivo, donde no se observan actos de ensañamiento y extrema crueldad en contra de los animales, sin perjuicio que con dicha conducta el animal experimenta un detrimento en su bienestar" 42 .

\subsubsection{Objeto}

El objeto material de la conducta, según el enunciado normativo, consiste en uno o más "animales", pues el actuar del hechor debe desplegarse a su respecto. Huelga preguntarse, entonces, ¿Qué se debe entender por ello?

En principio, es posible sostener que la expresión “animales” constituye un elemento normativo del tipo, pues la ley 20.380, en su artículo $2^{\circ}$, entiende por ellos a los "seres vivientes y sensibles que forman parte de la naturaleza" 43 . Como se lee, la genérica definición establece como requisito para que un ser sea considerado animal que éste posea vida, y sea capaz de sentir, sin distinguir entre especies ni establecer alguna otra cualidad diversa.

Dicho lo anterior, ha sido la doctrina la que ha intentado precisar este concepto, afirmándose que, por animal y para efectos de su protección penal, debe entenderse sólo a los vertebrados, pues ellos poseen "un sistema nervioso central, que les permite sentir dolor" 44 .

Si bien es cierto tal distinción es concordante con el objeto de la norma de protección, consistente en castigar a quien inflija al menos dolor a animales no humanos, la premisa básica de tal postulado, consistente en que sólo los vertebrados son aptos para sentir dolor, hoy se encuentra ampliamente cuestionada, existiendo cada vez más publicaciones y estudios que concluyen que ciertos invertebrados también pueden percibirlo y reaccionar conforme a él ${ }^{45}$.

El asunto no es baladí. Parece incuestionable que quien profiere extensas quemaduras a un perro o una vaca hasta causarle la muerte satisface los requisitos del tipo objetivo de la norma en análisis. Pero ¿qué ocurre con el cocinero que da muerte a una langosta utilizando el mismo medio comisivo, para llevarla, luego, a la mesa de un distinguido comensal? Una útil herramienta que permite solucionar este problema consiste en la "teoría de la adecuación social” propuesta originalmente por WELZEL, quien entiende por socialmente adecuadas "aquellas acciones determinadas o inducidas intrínsecamente por el ordenamiento éticosocial histórico de la vida en sociedad”, cuya ejecución impide, a juicio del autor, la satisfacción del tipo penal (en una primer planteamiento de WELzEL, quien, luego, postuló la exclusión de la antijuridicidad), pues en él deben entenderse incluidas sólo aquellas conductas socialmente inadecuadas, entendiendo por tales las que "exceden gravosamente el marco de los órdenes sociales históricamente dados”46. Contemporáneamente, hay autores que ven en el "riesgo permitido", entendido como factor excluyente de la imputación objetiva, algún grado de "parentesco" con la teoría de WelzEL, pues se atribuye a ambas instituciones factores externos y consecuencias similares ${ }^{47}$.

Así, en el ejemplo planteado, el cocinero que deja caer la langosta en agua hirviendo para lograr su cocción, si bien ejecuta una conducta que formalmente podría ser considerada

\footnotetext{
${ }^{42}$ Guzmán Dalbora, J. L. (2007). Estudios y defensas penales. Santiago de Chile: Lexis Nexis, pág. 237

${ }^{43}$ https://www.leychile.cl/Navegar?idNorma=1006858

${ }^{44}$ Guzmán Dalbora, J. L. (2007). Estudios y defensas penales (...), opus cit, pág. 239

${ }^{45}$ Vanda Cantón, B. (2 de Julio de 2017). El ser humano y los animales, pág. 3. Obtenido de Universidad Nacional Autónoma de México :

http://www.fmvz.unam.mx/fmvz/p_estudios/apuntes bioet/Unidad_2 dolor.pdf

${ }^{46}$ Eser, A. (2002). “La Adecuación social”: ¿Figura legal superflua o necesaria? Revista de derecho penal, Albert-Ludwigs-Universität Freiburg, pág. 459

${ }^{47}$ Cancio Meliá, M. (1993). La teoría de la adecuación social en Welzel. Anuario de derecho penal y ciencias penales, pág. 728
} 
como maltrato o crueldad y tal conducta va dirigida contra un ser vivo que muy probablemente tiene capacidad para sentir dolor, ciertamente no será sujeto de reproche penal pues su actuar no afecta al ordenamiento ético-social, el que acepta que esa especie en particular pueda ser tratada de la forma como lo ha hecho el cocinero, con miras a un fin ulterior que se estima superior.

\subsection{3. ¿Bien jurídico protegido?}

Siendo un pilar fundamental para los cultores del Derecho Penal liberal, se ha definido al bien jurídico como aquel "interés vital del individuo o de la comunidad" que "ha sido protegido por el Derecho" a través de la amenaza de un castigo ante toda o alguna forma de vulneración ${ }^{48}$.

Se atribuye a esta institución dos grandes funciones. En primer lugar, se asume en su necesaria concurrencia una limitación al ejercicio del ius puniendi estatal, pues se ha entendido que "las acciones privadas de los hombres que de ningún modo ofendan al orden público ni perjudiquen a un tercero, incluso las ofensas menores, están exentas de la autoridad de los magistrados" ${ }^{49}$. En segundo lugar, su utilidad queda de manifiesto en la posibilidad de clasificación de los delitos según el interés por ellos protegidos.

Expuesto lo anterior, es necesario precisar que, a pesar de tratarse de una institución esencial en la construcción de la dogmática penal moderna, su concurrencia como fundamento indispensable de la imposición del castigo se encuentra, hoy, en entredicho. Una influyente corriente doctrinaria contemporánea postula que el Derecho regula la relación entre personas, no entre personas y bienes jurídicos. Tal función reguladora es ejecutada mediante el establecimiento de normas jurídicas, las que no son más que la consagración de una expectativa social en un lugar y momento determinado. Dentro de ese contexto, el derecho penal se encarga de reglar la reacción social ante ciertas decepciones a aquellas expectativas, cuando la sociedad las ha estimado como especialmente relevantes. Así, la finalidad del castigo no consiste en retribuir una conducta lesiva a un bien jurídico determinado, ni prevenir que a futuro este sea lesionado nuevamente, sino que la imposición de la pena guarda relación con la reafirmación de la vigencia de la norma a través de la implementación de una reacción a su inobservancia. En esta dirección se ha dicho que "la garantía (del derecho penal ante el orden social) consiste en que las expectativas imprescindibles para el funcionamiento de la vida social, en la forma dada y en la exigida legalmente, no se den por perdidas en caso que resulten defraudadas” siendo, el bien a proteger, "la firmeza de las expectativas normativas esenciales frente a la decepción" 50.

Como se aprecia, la distinción parece ser más bien sutil. Sea que se trate del objeto de protección directo e inmediato de la norma jurídico-penal, sea que se trate del motivo que torne a una expectativa social como indispensable y la haga merecedora de consagración normativa jurídico-penal ${ }^{51}$, lo cierto es que lo que se ha entendido tradicionalmente por bien jurídico protegido juega un papel importante, especialmente como herramienta de interpretación teleológica.

Cabe ahora responder a la interrogante que motiva este apartado: ¿qué se protege cuando se establece o impone una sanción penal ante la ejecución de conductas constitutivas de maltrato a animales no humanos? O, desde una mirada más general, ¿por qué proteger a los animales no humanos a través de la ley?

La respuesta no es sencilla e, históricamente, son muchos quienes han intentado abordarla. En la antigüedad, EmpÉdocLes, PitÁGORAs, Platón y PorfiRio sostuvieron que

\footnotetext{
${ }^{48}$ Von Liszt, F. (2007). Tratado de derecho penal. Buenos Aires: Valletta, pág. 235

${ }^{49}$ Zaffaroni, E. R. (2002). Deecho penal, parte general. Buenos Aires: Ediar, pág. 127

${ }^{50}$ Jakobs, G. (1997). Derecho penal, parte general. Madrid: Marcial Pons, pág. 45.

${ }^{51}$ Kierszenbaum, M. (2009). El bien jurídico en el Derecho Penal, algunas nociones básicas desde la óptica de la discusión actual. Lecciones y Ensayos, Nº 86, pág. 197.
} 
la dignidad animal se encontraba a un nivel similar al de la dignidad humana, pues en la Grecia clásica rondaba la idea de la transmigración anímica, según la cual los animales en realidad eran humanos en cuerpos de bestias ${ }^{52}$. Mucho más tarde se planteó que, si bien la crueldad contra los animales debe ser evitada, no existe un deber ético directo (menos aun jurídico) del hombre hacia los animales, al carecer estos de razón, sino que se trata de una obligación “del hombre hacia sí mismo"53. Sin embargo, según explica CHIBLE, fue BENTHAM a fines del siglo XVIII quien abandonó la perspectiva filosófica antropocentrista con que se aproximaba a la interrogante, sosteniendo que la justificación ética de la protección animal no recae en la aptitud de tales seres para razonar, sino en su capacidad para padecer sufrimiento, sufrimiento que, consistente con la máxima utilitarista, debe ser evitado, afirmando que la ley penal debe prohibir "todo aquello que pueda servir de camino a la crueldad"54. Contemporáneamente, SinGER, sobre la base de lo propuesto por BENTHAM, formula el principio de igualdad entre especies, incluida la humana, pues si la protección se justifica éticamente en la proscripción del sufrimiento, todo sufrimiento debe ser contado de manera equivalente al "cualquier otro ser" 55 . Incluso más, se ha sostenido que, al menos mamíferos, aves y peces, deben ser considerados como sujetos de derechos básicos, en cuanto son "sujetos de una vida", al ser "conscientes del mundo, conscientes de lo que les ocurre e importándoles lo que les ocurre independientemente de que a alguien más le preocupe esto o no" 56 .

Dicho lo anterior, es necesario destacar que la doctrina penal chilena ha sido vacilante a la hora de determinar cuál es el bien jurídico protegido en el delito de maltrato animal. En este sentido, se ha indicado que lo pretendido es "proteger la convivencia pacífica de los miembros que la componen, ya que la violencia en contra de los animales, en el futuro puede implicar atentados delictivos más importantes”, salvaguardando el "orden y la seguridad pública”, negándose titularidad de interés o derecho alguno al animal ${ }^{57}$.

Sin embargo, como se ha adelantado, la normativa en vigor resuelve expresamente tal interrogante, aclarando que lo protegido es la "salud y el bienestar animal", por lo que el deber de conducta exigido por el ordenamiento jurídico se verá infringido cuando se provoque dolor o sufrimiento a un animal no humano, sea física o mentalmente, sea que se generen consecuencias corporales o no. De este modo, aparece implícito que el legislador, entendiendo que los animales son seres sintientes, reconoce en su favor un derecho básico, consistente en la proscripción de todo acto humano deliberado que cause dolor, declaración que, como se analizará más adelante, posee variadas -y a veces odiosas- excepciones.

Con todo, entender que el animal no humano constituye, en sí, un objeto de protección, recoge una larga aspiración doctrinaria, pues la academia ha sostenido reiteradamente que, debido a sus especiales condiciones como seres sintientes dotados incluso de inteligencia, a los animales debe conferírseles cierta protección autónoma, aceptando "la existencia de un bien jurídico referido a la integridad física y psíquica del animal como ser vivo" 58 .

\footnotetext{
${ }^{52}$ Escobar Gómez, S. (1997). De un predecesor árabe de Bentham en la defensa de los 'derechos de los animales". Anaquel de Estudios Árabes, pág. 89.

${ }^{53}$ Kant, I. (2002). Lecciones de ética. Barcelona : Crítica, pág. 137

${ }^{54}$ Chible Villadangos, M. J. (2016). Introducción al Derecho Animal. Elementos y perspectivas. Revista ius et praxis, año 22, N²2, pág. 396.

${ }^{55}$ Singer, P. (1999). Liberación Animal. (...), opus cit., pág. 44.

${ }^{56}$ Regan, T. (2007). Derechos animales y ética medioambiental. Studia Philosophica, 117-130, pág. 122

${ }^{57}$ De Carvalho González, E. (2016). La comisión por omisión en el delito de maltrato o crueldad animal (...) opus cit., pág. 13.

${ }^{58}$ Ríos Corbacho, J. M. (18 de 09 de 2017). Los animales como posibles sujetos de Derecho Penal, pág. 22. Obtenido de Algunas referencias sobre los artículos 631 (suelta de animales feroces o dañinos) y 632 (malos tratos crueles) del Código Penal español: 


\subsubsection{Sujeto activo}

De la simple lectura de los artículos 291 bis y 291 ter del Código Penal Chileno ${ }^{59}$, se concluye que, en su modalidad de comisión activa, el maltrato animal es un delito común, pues la conducta exigida para guardar la debida fidelidad a la norma, lo es respecto de cualquier persona. En cambio, cuando se trata de la posibilidad de comisión por omisión la respuesta no es la misma, ya que la conducta debida, consistente en ejecutar la acción necesaria para evitar el daño, dolor o sufrimiento del animal, es exigida respecto de ciertas personas que, en el caso concreto, se encuentran en lo que la doctrina denomina como “posición de garante” respecto del animal, asunto que se explicará en lo venidero de esta investigación.

\subsubsection{Sujeto pasivo}

Clarificado que, hoy, el bien jurídico protegido por la legislación penal chilena es el bienestar animal, el titular de dicho interés es precisamente el animal no humano, por lo que es posible concluir que en esta figura típica existe coincidencia entre el sujeto pasivo y el objeto material del delito, motivo por el cual daremos por reproducido, aquí, todo lo razonado supra en relación con ello.

\subsubsection{Medios comisivos}

Para la ley resulta indiferente qué medio o mecanismo se utilice para causar el daño, dolor o sufrimiento del animal, pudiendo tratarse de medios materiales o incluso inmateriales, lo que queda en evidencia con el reconocimiento expreso de la comisión por omisión, y es perfectamente compatible con lo postulado con antelación en cuanto a que el bien jurídico protegido por la norma es el bienestar animal, estado que comprende aspectos corporales e incorporales del sujeto pasivo.

Asimismo, la ley, específicamente el artículo 291 ter del Código Penal Chileno, se encarga de aclarar que la conducta no necesariamente debe ser reiterada o permanente en el tiempo, afirmando que también constituyen maltrato o crueldad actos u omisiones ocasionales

\subsubsection{Formas de ejecución}

Hasta antes de la última modificación normativa sobre la materia, una ardua discusión doctrinaria versaba sobre si el delito de maltrato animal admitía la posibilidad de comisión por omisión, o si, por el contrario, su supuesto de hecho sólo se podía configurar con la ejecución de una conducta.

Una posición negativa realizaba una interpretación exegética del actual inciso $1^{\circ}$ del artículo 291 bis del Código Penal, restringiendo la satisfacción del tipo objetivo a la “comisión de actos”, lo que, se afirmaba, impedía la posibilidad de comisión por omisión.

Otros, en cambio, acudiendo a herramientas sistemáticas recordaban que el artículo $3^{\circ}$ de la Ley 20.380, sobre protección de animales, señala: “Toda persona que, a cualquier título, tenga un animal, debe cuidarlo y proporcionarle alimento y albergues adecuados, de acuerdo, al menos, a las necesidades mínimas de cada especie y categoría y a los antecedentes aportados por la ciencia y experiencia” 60 .

\footnotetext{
${ }^{59}$ https://www.leychile.cl/Navegar?idNorma=1984

${ }^{60}$ https://www.leychile.cl/Navegar?idNorma=1006858 
A partir de dicha regla se concluyó que existe una especial posición de garante ${ }^{61}$, donde el tenedor material del animal no humano resulta responsable por su bienestar, dando pie a la posibilidad de comisión por omisión.

Tal propuesta, evidentemente bien intencionada, resulta difícil de compartir. Es correcto afirmar que la regla antes señalada ha establecido una serie de obligaciones que deben ser satisfechas por el tenedor de un animal, y puede ser considerada como una verdadera posición institucional de garante respecto de su bienestar. Pero de ello no es posible afirmar, necesariamente, que el artículo $3^{\circ}$ de la Ley 20.380 sea una norma con contenido jurídico penal, pues, por un lado, su infracción no trae aparejada expresamente sanción alguna, mientras que la única regla con contenido penal contemplada en dicho cuerpo normativo se encuentra en su artículo 18, en cuanto modifica el artículo 291 bis del Código Penal $^{62}$. En el mismo sentido, podría afirmarse que si el legislador hubiese pretendido incluir la posibilidad de comisión en la configuración del delito de maltrato o crueldad animal lo hubiere realizado expresamente, incorporándolo en su enunciado. Finalmente, por extensivo que sea el ejercicio interpretativo, resulta imposible incluir en el enunciado "el que cometiere actos de maltrato o crueldad...” la posibilidad de comisión por omisión, al ser, la omisión, precisamente el antónimo de la voz "acto", por lo que la teoría en análisis echa mano a una verdadera analogía in malam partem, atentando, así, contra el principio de legalidad.

No obstante lo anterior, hoy el asunto ha sido resuelto mediante la redacción actual del artículo 291 ter, norma que, a la letra, señala: "Para los efectos del artículo anterior se entenderá por acto de maltrato o crueldad con animales toda acción u omisión...”63. Dicho aquello, huelga precisar que la extensión de la posibilidad de comisión omisiva es restringida, pues, como resulta lógico, sólo podrá incurrir en tal conducta quien tenga la obligación de ejecutar la acción necesaria para evitar el daño, dolor o sufrimiento del animal. Tal obligación o conjunto de obligaciones, consiste en lo que la doctrina penal denomina "posición de garante", entendiendo por tal institución a una "estrecha relación que liga” al sujeto activo de la conducta con "el bien jurídico tutelado” 64 , cuya fuente, según KAUFMANN, se encuentra en el contrato, la ley o su conducta precedente ${ }^{65}$.

En lo que concierne a esta investigación, tal estrecha relación existe entre el tenedor y el animal, y conlleva la obligación de proveer a este último de todos los medios necesarios para asegurar su bienestar, por lo que la configuración y la necesaria posición de garante y, por tanto, la posibilidad de comisión por omisión del delito de maltrato o crueldad animal, ocurrirá sólo respecto de animales domésticos o animales de granja, pues, como se ha dicho, será necesario que, por su naturaleza, admitan la posibilidad de tenencia, lo que no ocurre con animales salvajes, asilvestrados o ferales, quienes, por regla general, tampoco requieren el auxilio humano para satisfacer los requerimientos propios de su bienestar.

\subsection{8. ¿Delito de resultado?}

Otra discusión superada, pero no por ello irrelevante, consiste en si el delito de maltrato o crueldad es de aquellos denominados "de mera actividad" o si, por el contrario, requiere la concurrencia de un resultado. La disyuntiva se origina en la total ausencia de referencia al resultado en la anterior redacción del inciso primero del artículo 291 bis del Código Penal. No obstante, prácticamente la unanimidad de la doctrina y jurisprudencia postulaba que las expresiones "maltrato” y “crueldad” suponen la necesaria existencia de

\footnotetext{
${ }^{61}$ De Carvalho González, E. (2016). La comisión por omisión en el delito de maltrato o crueldad animal (...), opus cit., pág. 95

${ }^{62}$ https://www.leychile.cl/Navegar?idNorma=1984

${ }^{63}$ Ibidem.

${ }^{64}$ Bacigalupo, E. (1970). Conducta precedente y posición de garante. Problemas actuales de las Ciencias Penales y de la Filosofía del Derecho en homenaje a Jiménez de Asúa, pág. 38

${ }^{65}$ Mir Puig, S. (2008). Derecho Penal, Parte General. Buenos Aires: BdeF, pág. 318.
} 
dolor, lo que debía ser considerado como señal inequívoca de exigencia de un resultado ${ }^{66}$.

Hoy el asunto es claro, el maltrato y la crueldad poseen definición legal, requiriendo, el artículo 291 ter, que la acción u omisión cause "daño, dolor o sufrimiento animal”67. Respecto de qué debe entenderse por daño, dolor o sufrimiento, se estará a lo expuesto en el acápite 4.1.3. de esta investigación.

Ahora bien, otro asunto conflictivo que puede requerir especial atención del interprete consiste en la eventual ejecución de una acción u omisión que cause la muerte indolora de un animal. El asunto es el siguiente: El inciso $1^{\circ}$ del artículo 291 bis del Código Penal proscribe la comisión de actos de "maltrato o crueldad con animales"; luego, como se ha dicho, el artículo 291 ter define al "maltrato o crueldad con animales" como "toda acción u omisión, ocasional o reiterada, que injustificadamente causare daño, dolor o sufrimiento al animal" 68; finalmente, el inciso $3^{\circ}$ del artículo 291 bis ordena imponer una pena mayor "si como resultado de las referidas acción u omisión se causaren lesiones que menoscaben gravemente la integridad física o provocaren la muerte del animal”69.

Como se lee, provocar la muerte indolora de un animal no humano constituye un hecho impune para la legislación penal chilena, pues la muerte constituye un especial resultado, secundario y accesorio al resultado original inherente al concepto de maltrato o crueldad, que tiene por finalidad incrementar la respuesta punitiva, sin modificar la conducta. Así, la elevada pena contemplada en el inciso tercero de artículo 291 bis del Código Penal chileno requiere, para la configuración del injusto típico, la ejecución de una acción u omisión, que cause injustificado daño, dolor o sufrimiento a un animal, concluyendo en su muerte.

\subsection{Elementos del tipo subjetivo}

De la lectura de la norma en estudio, no se aprecia la exigencia de requisitos especiales, sea volitivos o cognoscitivos, que permitan modificar el régimen general doctrinario, siendo admisible su comisión con dolo directo o eventual.

Respecto de la figura culposa o imprudente, entendiendo por ella a aquella conducta “que lesiona el grado de cuidado requerido en el ámbito de relación, produce de un modo no doloso un resultado típico" 70 , debe ser precisado que el Código Penal chileno restringe su punibilidad sólo a los delitos "contra las personas"71, dentro de los cuales no se encuentra el maltrato o crueldad animal, por lo que este supuesto resultaría impune al tratarse de un hecho subjetivamente atípico.

\subsection{Antijuricidad}

Los cultores de las ciencias penales sostienen que, para que una determinada conducta pueda ser considerada como delito, no basta con la ejecución del comportamiento humano de manera dolosa o imprudente, pues "puede suceder que tal comportamiento se halle justificado por la concurrencia de una causa de justificación”, figura que excluirá la antijuridicidad “y desaparecerá la posibilidad de considerar que la misma constituya delito"72.

Es tal vez en este aspecto donde, aún hoy, se manifiesta una especial pugna o

\footnotetext{
${ }^{66}$ Guzmán Dalbora, J. L. (2007). Estudios y defensas penales (...), opus cit., pág. 238

${ }^{67} \mathrm{https}: / /$ www.leychile.cl/Navegar?idNorma $=1984$

${ }^{68}$ Ibidem.

${ }^{69}$ Ibidem.

${ }^{70}$ Horvitz, M. I., \& López, J. (2004). Derecho Procesal Penal Chileno. Santiago de Chile: Editorial Jurídica de Chile, pág. 143

${ }^{71}$ https://www.leychile.cl/Navegar?idNorma=1984

${ }^{72}$ Mir Puig (2008) Derecho Penal, Parte General (...), opus cit., pág. 421 
distancia entre la evolución de la moralidad social y aquella recogida por la ley, pues, como se verá, múltiples conductas que satisfacen los requisitos objetivos y subjetivos del enunciado típico de maltrato o crueldad animal no podrán ser consideradas injustas o contrarias a derecho, al encontrarse amparadas en sendas causales de justificación contempladas en la ley.

\subsubsection{Aplicabilidad de las causales de antijuridicidad genéricas}

Antes de analizar aquellas causales de justificación especiales o específicas pertinentes al delito en estudio, resulta necesario dedicar algunas líneas al estudio de ciertas particularidades que resultan relevantes a la hora de determinar la aplicabilidad de las causales de justificación genéricas comprendidas en la ley, al no estar ellas excluidas expresamente respecto del delito de maltrato o crueldad animal.

Habiendo ya concluido que el bien jurídico tutelado por el delito en cuestión radica en el bienestar animal y, en ningún caso, algún derecho real que pueda poseer la persona que ejerce su tenencia, si la hubiere, es posible descartar la justificación de la conducta constitutiva de maltrato o crueldad a pretexto del consentimiento del ofendido o el estado de necesidad justificante. Respecto del consentimiento, el asunto parece evidente: El ofendido con la ejecución de la conducta típica es el animal, en su calidad de ser sintiente sin perjuicio de carecer de voluntad, atributo que constituye un requisito de la esencia del consentimiento.

En cuanto al estado de necesidad justificante, el artículo 10 Nº del Código Penal chileno prescribe que se encuentra en aquella circunstancia "el que para evitar un mal ejecuta un hecho, que produzca daño en la propiedad ajena" ${ }^{73}$. Entonces, aun siendo innegable que el animal puede ser objeto de propiedad desde una perspectiva civil, el "daño” provocado por la conducta de maltrato o crueldad excede, por mucho, el mero detrimento patrimonial de su dueño, por lo que su sacrificio no puede entenderse justificado a través de esta vía.

Por cierto, la legitima defensa tampoco puede ser considerada como causal de justificación, pues para justificar la conducta del defendido, la acción defensiva debe ir dirigida contra el injusto agresor, situación en la que no podrá incurrir un animal no humano ante la imposibilidad de ser sujeto de reproche jurídico por su actuar. Incluso es más, con toda claridad se ha afirmado que la amenaza a bienes jurídicos del defendido debe provenir "de una conducta humana"74.

Finalmente, resulta interesante analizar el caso de las causales de justificación donde el interés preponderante consiste en el legítimo ejercicio de un derecho, autoridad, oficio o cargo, o en el cumplimiento de un deber. Estas hipótesis poseen una especial incidencia práctica, pues existen variadas actividades reguladas, donde el daño, dolor o sufrimiento animal constituyen consecuencias posibles o necesarias en su desarrollo. En este sentido, son plenamente exigibles los requisitos generales para la procedencia de la justificante, consistentes en: a) la titularidad del derecho, autoridad, oficio o cargo; b) el actuar dentro de la competencia del sujeto activo en los últimos dos casos; y, c) el daño, dolor o sufrimiento provocado al animal debe ser proporcional e indispensable a la finalidad pretendida por el hechor.

No obstante, la nueva ley sobre tenencia responsable de mascotas y animales de compañía restringe la operatividad de esta causal de justificación, al prohibir expresamente, en su artículo $7^{\circ}$ inciso $2^{\circ}$, "la utilización de métodos que admitan el sacrificio de animales como sistema de control de la población animal. Esta prohibición se extiende a todos los servicios públicos, así como también a todas las organizaciones de protección animal”75.

\footnotetext{
${ }^{73}$ https://www.leychile.cl/Navegar?idNorma=1984

${ }^{74}$ Welzel, H. (2011). Derecho penal alemán. Santiago de Chile: Editorial Jurídica de Chile, pág. 138

${ }^{75}$ https://www.leychile.cl/Navegar?idNorma=1006858
} 


\subsubsection{Causales de justificación especiales contempladas en la Ley $\mathbf{2 0 . 3 8 0}$}

La ley 20.380, sobre protección animal, contiene una serie de situaciones específicas a las que no se extiende su regulación y, por ello, se trata de conductas permitidas por el derecho que, prima facie, no pueden ser consideradas como antijurídicas para efectos penales.

En primer lugar, la ley permite la realización de experimentos en animales vivos con tal que "se evite al máximo su padecimiento"76, autorizando implícitamente al experimentador para causar daño, dolor o sufrimiento al animal. Acto seguido, la normativa exige que todo procedimiento de experimentación se practique por "personal calificado", en tanto ordena que toda intervención quirúrgica sea ejecutada por un médico veterinario.

Otra actividad lícita contemplada en la norma consiste en el beneficio y sacrificio de animales para el consumo humano, bajo exigencia de emplear "métodos racionales tendientes a evitarles sufrimientos innecesarios"77, lo que implica, nuevamente, aceptar que se cause sufrimiento al animal sacrificado cuando ello se requiera.

Luego, una polémica causal de justificación se comprende en el artículo 16 de la ley, cuando expresamente sustrae de su ámbito de aplicación -entre el que se encuentra el inciso $1^{\circ}$ del artículo 291 bis del Código Penal- "a los deportes en que participen animales, tales como el rodeo, las corridas de vaca, el movimiento a la rienda y los deportes ecuestres, los que se regirán por sus respectivos reglamentos"78.

Finalmente, el artículo 16 de la ley dispone que las actividades de caza y pesca se rigen preferentemente por su regulación sectorial, lo que significa que, en tanto se adecuen a ella, el daño, dolor o sufrimiento que se cause a los animales involucrados no podrá ser constitutivo de maltrato o crueldad para efectos penales.

\subsection{Culpabilidad}

Este elemento de la teoría del delito puede ser definido como aquel "encargado de reunir aquellas circunstancias que condicionan la reprochabilidad del hecho antijurídico", permitiendo atribuirlo a su autor ${ }^{79}$. Se comprenden aquí las siguientes categorías: La imputabilidad, la posibilidad de conocer lo injusto del actuar y la ausencia de causales de exculpación.

Dicho lo anterior, huelga afirmar que el delito de maltrato o crueldad animal no genera alteraciones al régimen general de la culpabilidad, por lo que no será especial objeto de este estudio.

\subsection{Particularidades}

Para finalizar el presente capítulo, se expondrán tres situaciones que requieren particular atención, debido las consecuencias que su eventual acaecimiento puede producir en el razonamiento judicial y, en definitiva, en la respuesta punitiva.

\subsubsection{Pluralidad de conductas o delitos}

Los artículos 74 y 75 del Código Penal chileno ${ }^{80}$ regulan la penalidad aplicable a los

\footnotetext{
${ }^{76}$ Ibidem.

${ }^{77}$ Ibidem.

${ }^{78}$ Ibidem.

${ }^{79}$ Mir Puig (2008) Derecho Penal, Parte General (...), opus cit., pág. 532

${ }^{80}$ https://www.leychile.cl/Navegar?idNorma=1984
} 
concursos reales (o materiales) e ideales de delitos, disponiendo la acumulación de las penas en el caso de producirse un concurso real, y ordenando la aplicación de la pena más intensa asignada al delito más grave, en el evento de originarse un concurso ideal.

Se estará en presencia de un concurso real "cuando un mismo sujeto ha realizado dos o más acciones que constituyen, a su vez, uno o más delitos independientes no conectados entre sí y sin que en relación a ninguno de ellos se haya dictado sentencia condenatoria" ${ }^{81}$. En cuanto al delito de maltrato o crueldad animal, es posible afirmar que siempre que el autor ejecute conductas diversas provocando daño, dolor o sufrimiento a más de un animal, se estará ante un concurso real, debiendo procederse a la acumulación de cada una de las penas, descartándose la posibilidad de entender tales conductas sólo como un delito reiterado, pues se trata de ataques múltiples a un bien jurídico individual, como lo es el bienestar de cada uno de los animales involucrados, asimilable a aquellos denominados como “personalísimos”, por lo que cada lesión ocasionada no guarda relación con las demás y debe ser castigada de manera aislada, a menos que guarden una "relación temporoespacial inmediata" 82 .

A su turno, existirá un concurso ideal de delitos "cuando una acción o un conjunto de acciones unitariamente consideradas, cumplen las exigencias de dos o más figuras penales; en otros términos, constituye coetáneamente dos o más delitos distintos"83. Esta figura tendrá especial incidencia en aquellas actividades reguladas relacionadas con animales, como ciertos deportes, la caza, la pesca, la experimentación con animales vivos, los circos, las actividades veterinarias, entre otras, pues si sus parámetros regulatorios son excedidos por el hechor causando con ello daño, dolor o sufrimiento a un animal, se incurrirá tanto en el delito de maltrato o crueldad, como en la infracción que contemple la norma sectorial pertinente, si la hubiere, debiendo agravarse la pena según lo prescrito por el artículo 75 del Código Penal chileno antes mencionado.

\subsubsection{Iter criminis}

En principio, tratándose de un delito de resultado, el maltrato o crueldad animal admite la posibilidad consumación y de tentativa, sea ésta acabada o inacabada. No obstante, el asunto parece no ser tan sencillo, pues en el caso de esta figura típica los actos que anteceden al resultado serán generalmente lícitos, debido a la gran aptitud del humano para provocar tales consecuencias, la especial indefensión del animal víctima del ilícito, y la frecuente clandestinidad de la conducta lesiva. En segundo lugar, se trata de una víctima que no posee capacidad expresiva, por lo que, en ausencia del resultado, la expectativa de enjuiciamiento de la tentativa se verá radicalmente restringida.

\subsubsection{Maltrato animal y daños}

Por último, asumido que el bien jurídico protegido por el Derecho Penal es el bienestar animal, pero reconociendo que para el derecho privado ciertos animales son objeto de apropiación humana, resulta interesante analizar la relación entre la figura típica de maltrato o crueldad y aquella que castiga la provocación de daños.

Atendida la dicotomía planteada en el párrafo precedente, se concluye que frente una conducta que cause un daño de tal envergadura que disminuya el valor patrimonial que un determinado animal representa para su dueño, existirá un concurso aparente de leyes penales, institución que puede definirse como "una situación en la cual son a primera vista aplicables varias disposiciones penales, pero que en realidad se rigen por una sola de ellas, quedando

\footnotetext{
${ }^{81}$ Garrido Montt, M. (2003). Derecho Penal, Tomo II. Santiago de Chile: Editorial Jurídica, pág. 344

${ }^{82}$ Welzel, H. (2011). Derecho penal alemán (...), opus cit., pág. 334

${ }^{83}$ Garrido Montt, M., (2003). Derecho Penal, Tomo II (...), opus cit. pág. 348 
las otras totalmente desplazadas" ${ }^{84}$. Tal problema concursal debe resolverse a través del principio de especialidad, pues el régimen punitivo aplicable al delito de maltrato o crueldad, más allá de su intensidad, es específico respecto de aquel asignado al delito de daños, lo que queda en evidencia si se piensa en la posibilidad de aplicar medidas reparatorias respecto del animal, o la prohibición de tenencia como pena accesoria, intervenciones que no resultan procedentes ante la simple figura de daños.

\section{EVOLUCIÓN JURISPRUDENCIAL DEL DELITO DE MALTRATO ANIMAL}

Entrando ya a lo medular de esta investigación, se expondrá en lo venidero un puñado de casos que fueron objeto de decisión por los tribunales con competencia penal en Chile, lo que permitirá dejar en evidencia la manera en que se ha dotado de contenido a los enunciados normativos ya estudiados, y se ha aplicado las consideraciones doctrinarias antes vistas.

Para promover el correcto entendimiento del lector, es necesario señalar, a modo de preámbulo, que el sistema de enjuiciamiento criminal en Chile supone una estricta separación de la función investigativa respecto de la función decisoria o atributiva, lo que constituye una clara manifestación del sistema acusatorio ${ }^{85}$. Así, la investigación penal es desarrollada por un órgano autónomo, denominado Ministerio Público, a través de funcionarios estatales llamados Fiscales. El control de la investigación, cuando ella amerite la restricción de derechos fundamentales del imputado, es ejercido por órganos jurisdiccionales denominados Juzgados de Garantía, quienes autorizan o rechazan la ejecución de medidas intrusivas o vulneradoras de derechos fundamentales ${ }^{86}$.

Por su parte, la función decisoria o atributiva es ejecutada por los tribunales de justicia con competencia penal, dentro de los que se encuentran los propios Juzgados de Garantía (tribunales unipersonales), cuando se solicite por el Ministerio Público la aplicación de penas no privativas de libertad, o penas privativas de libertad escasamente intensas, o por Tribunales de Juicio Oral en lo Penal (tribunales colegiados compuestos por tres jueces), cuando la pena solicitada supere cierto límite ${ }^{87}$.

Ahora, desde una perspectiva adjetiva o procedimental, la ley, en especial el Código Procesal Penal, contempla diversos procedimientos dependiendo de la complejidad y gravedad del asunto objeto de juzgamiento. Así, la primera gran clasificación se encuentra entre aquellos procedimientos cuyo término consiste en una sentencia judicial, sea condenatoria o absolutoria, y aquellos procedimientos que concluyen a través de "formas alternativas de resolución del conflicto” penal ${ }^{88}$. Dentro de esta última categoría, el método más relevante consiste la suspensión condicional del procedimiento, institución a través de la cual el imputado se obliga a cumplir ciertas condiciones propuestas por el Ministerio Público por un lapso no superior a un año, cuya observación deriva en el sobreseimiento definitivo. También pertenece a esta clase de procedimientos el acuerdo reparatorio, aplicable a aquellos casos donde lo que se discute es la infracción a normas que cautelan bienes jurídicos patrimoniales y disponibles, habilitando a la víctima para pactar con el imputado el término de la persecución penal si este ejecuta ciertas medidas de reparación en su favor.

Por su parte, los procedimientos que concluyen con sentencia judicial son clasificables en procedimientos auto-incriminatorios o de juicio oral. Son procedimientos

\footnotetext{
${ }^{84}$ Etcheberry, A. (2005). Derecho penal, parte general, tomo II. Santiago de Chile: Editorial Jurídica de Chile, pág. 122

${ }^{85}$ Maturana, C. (2012). Derecho procesal penal. Santiago de Chile: Thomson Reuters, pág. 109.

${ }^{86}$ Chahuán, S. (2012). Manual del nuevo procedimiento penal. Santiago de Chile: Thomson Reuters, pág. 42

${ }^{87}$ https://www.leychile.cl/Navegar?idNorma=176595

${ }^{88}$ Duce, M., \& Riego, C. (2011). Proceso penal. Santiago de Chile: Editorial Jurídica de Chile, pág. 283
}

166 Derecho Animal. Forum of Animal Law Studies, vol. 9/3 
auto incriminatorios el procedimiento simplificado, donde el imputado derechamente admite responsabilidad en los hechos a él atribuidos por el Ministerio Público ${ }^{89}$, y el procedimiento abreviado, en que el imputado acepta como verdaderos los hechos de la imputación y los antecedentes allegados a la investigación fiscal ${ }^{90}$. Si bien es cierto en cualquiera de los casos es posible que se arribe a una sentencia absolutoria, las probabilidades que ello ocurra se ven reducidas drásticamente debido a la renuncia a buena parte de los elementos propios de una adecuada defensa técnica.

Finalmente, dos son también los procedimientos que concluyen con la realización de un juicio oral: El juicio oral simplificado y el procedimiento ordinario. Tal como se ha dicho, el primero será desarrollado ante un Juez de Garantía, y procederá siempre que no se solicite por el ente persecutor una pena privativa de libertad superior a 541 días. Si la cuantía de la pena solicitada es superior, el juicio oral debe llevarse a cabo ante un tribunal colegiado, denominado Tribunal de Juicio Oral en lo Penal.

\subsection{Caso Nº 1 : "Ramba”}

En sentencia dictada el 20 de marzo de 2013 por el Juzgado de Garantía de San Bernardo, Región Metropolitana de Santiago ${ }^{91}$, luego de la realización de un juicio oral simplificado, se resolvió el que, tal vez, sea caso más emblemático de maltrato animal conocido por los tribunales con competencia penal en Chile, cuya víctima fue un elefante asiático de sexo femenino, que era explotada por uno de los circos más tradicionales del país.

\subsubsection{Imputación}

Se planteó como objeto del juicio los siguientes hechos: Entre los años 2007 y 2010, el imputado J.G.M.Q. realizó diversos espectáculos públicos circenses en varias comunas de Chile, incluyendo las comunas de Santiago, Rancagua, Quilpué y Buin entre otras, en los cuales exhibió y utilizó indebidamente y con ánimo de lucro a un elefante asiático hembra de nombre "Ramba”, especie en peligro de extinción y, como tal, incluida en el apéndice 1 del convenio CITES $^{92}$, acción que desarrolló en forma habitual.

Se especificó que, desde septiembre del 2010 hasta el 5 de diciembre del 2011, el sujeto antes mencionado mantuvo, a sabiendas, dicha especie en condiciones inadecuadas de temperatura, salud e higiene, lo que provocó en "Ramba" hipotermia reiterada, daño en las patas por falta de aseo y de un correcto despalme, e imposibilidad de un adecuado descanso al no contar con las condiciones necesarias para ello en su lugar de cautiverio.

Luego, en la sentencia el tribunal constata una historia trágica, pues ya en 1997 el servicio agrícola ganadero -en adelante SAG- había ordenado el comiso del mismo animal en virtud de una resolución administrativa, al no poder acreditar, su tenedor, el origen o dominio de la elefanta.

Posteriormente, el animal, no obstante estar comisado, fue vendido ilegalmente a J.G.M.Q., propietario del circo "Los tachuelas” y, producto de una nueva denuncia, el mismo servicio volvió a pronunciarse respecto de este animal ya decomisado y de otras especies salvajes también protegidas por la convención CITES, mediante resolución 380, de 2 de febrero de 2004 en causa rol 585-2001, oportunidad en que el SAG confirma el comiso ya realizado respecto al paquidermo y ordena lo pertinente en relación a los demás animales que en el año 2003 estaban en poder del propietario del circo, a saber, 3 leones, 5 tigres y 8 monos papiones, todos sin acreditación de origen legal. El tenedor de los animales antes referidos

\footnotetext{
${ }^{89}$ Horvitz, M. I., \& López, J. (2004). Derecho Procesal Penal Chileno. Santiago de Chile: Editorial Jurídica de Chile, pág. 459

${ }^{90}$ Maturana, C. (2012). Derecho procesal penal (...), opus cit., pág. 1110.

${ }^{91}$ https://www.dropbox.com/s/5dlrw9ued17o8n8/Sentencia\%201.pdf?dl=0

${ }^{92}$ CITES. (1973). https://cites.org/esp/disc/text.php
} 
era J.G.M.Q, quien los mantuvo bajo cuidado mínimos y sujetos a falta de condiciones indispensables para su sobrevivencia, encontrándose en ambientes inhóspitos, mal alimentados, sometidos a estrés permanente por las condiciones de hacinamiento y falta de higiene, así como falta de cuidados médicos veterinarios indispensables en relación a cada especie, requisito mínimo al tratarse de especies silvestres en cautiverio, según se logró establecer mediante peritajes efectuados, en especial, respecto a la elefanta "Ramba", circunstancia que fue constatada por un experto en fauna silvestre.

Luego, el juez asegura que en el caso del paquidermo en cuestión existen imágenes que demuestran ausencia total de bienestar, atribuible al actuar directo del tenedor, al consentir y propiciar la exposición directa de las patas de "Ramba" a su propia orina y excrementos, sin proporcionarle una mínima área de desplazamiento en las instalaciones del circo.

Afirma, acto seguido, que el estado de sujeción a una cadena o cuerda metraje por tiempo prolongado fue registrado de forma reiterada en imágenes tomadas en diversas ocasiones, incluso de forma reciente durante el año 2010. Igualmente, se encuentra registrado que dicho espécimen ingería papeles y cartones según da cuenta informe que se rindió en juicio, y que mantuvo una exposición prolongada a su propio excremento y orina por incapacidad de desplazarse siquiera dos metros de costado. Se suma a estas condiciones la sobreexposición al público con riesgos de seguridad para las personas y para el animal, unido a los recurrentes episodios de hipotermia en periodo invernal y ausencia de certificación sanitaria, el encontrarse prácticamente inmovilizada durante la mayor parte del tiempo, y el inevitable acaecimiento de problemas en su ciclo digestivo y enfermedades asociadas.

Constata, por otra parte, que los demás animales se encontraban en pésimas condiciones higiénicas, de estrés, de alimentación y de cuidados mínimos, señalando, a modo de ejemplo, que algunos felinos ciegos se mantenían en dependencias de un subterráneo.

Finalmente, concluye el sentenciador que el imputado faltó a su deber de cuidado posición de garante- en su calidad de custodio de un animal exótico, en peligro de extinción y protegido internacionalmente, es decir, afirma que él tenía mayores obligaciones y deberes derivado del tipo de especie, no siendo suficiente tenerla encerrada, encargar el trabajo podal a quien no tenía capacitación, encargar el cuidado médico a quien no estaba capacitado, y encargar el cuidado diario a quienes no realizaban lo que decían hacer. Nunca supervisó ni menos le brindó lo necesario, en circunstancias que si lo podía hacer.

\subsubsection{Decisión}

El tribunal condenó al imputado como autor del delito consumado de maltrato animal, a sufrir una pena de 100 días presidio menor en su grado mínimo (pena que fue remitida condicionalmente durante 1 año), multa de 10 unidades tributarias mensuales (615€, aproximadamente), y a la pena accesoria de suspensión para cargos u oficios públicos durante el tiempo que dure la condena.

\subsubsection{Análisis del caso}

Desde un principio, los hechos antes expuestos dejan en evidencia el rotundo fracaso del sistema de fiscalización chileno, al haberse expuesto a un animal protegido a reiterados episodios de maltrato pues, como se ha dicho, éste ya había sido incautado en 1997 a un antiguo propietario. Por lo demás, que los hechos que motivan la sentencia se hayan extendido durante más de 3 años y cometido en al menos 4 ciudades diferentes permiten ratificar dicha conclusión.

Un aspecto a destacar consiste en la correcta determinación hecha por el juez en la sentencia respecto del bien jurídico protegido, el que identificó como el bienestar del elefante, logrando desarrollar algunos aspectos que influyeron negativamente en la configuración de tal estado. Así, fue verificada la existencia de las siguientes vulneraciones: 
A la facilidad de movimiento, pues el animal se mantuvo inmovilizado sin poder desplazarse siquiera dos metros; al confort térmico, ya que el elefante registró reiterados episodios de hipotermia; al descanso, debido a la sobreexposición al público y el estado de hacinamiento en que se encontró; y a la ausencia de enfermedad, al no suministrarle los cuidados veterinarios e higiénicos adecuados.

Por otro lado, se aprecia que el juez dio por establecida la comisión por omisión del delito de maltrato o crueldad animal, asunto que era objeto de discusión con anterioridad a la ley 21.020, atribuyendo al condenado la posición de garante respecto del bienestar del paquidermo, dada su condición de "tenedor de un animal exótico". Siendo tal construcción un esfuerzo valorable, resulta evidente que su corrección queda en entredicho, pues muchas de las conductas descritas en la imputación no pueden ser consideradas propiamente como omisiones. Así, no se puede entender como omisión la sobrexposición del animal al público, su encadenamiento permanente o su encierro en un lugar insalubre o confinado. Es el tenedor quien ejecuta conductas activas para poner al elefante en tales circunstancias, y la omisión de cese no produce otro efecto distinto al de prolongar la etapa de desarrollo del ilícito.

Tal vez el aspecto más lamentable de la decisión, sin ser responsabilidad del juez, consiste en el leve castigo impuesto al autor de tan crudos hechos. Por una parte, se impone una pena privativa de libertad que es sustituida por la posibilidad de cumplimiento en libertad, mediante la figura denominada "remisión condicional de la pena" que, en concreto, conlleva la simple obligación de presentarse ante la autoridad una vez al mes para efectos de control, mientras que la multa impuesta puede ser considerada como irrisoria si se considera que los actos de maltrato fueron ejecutados en el contexto de la explotación comercial del animal lo que, muy probablemente, trajo aparejado un rédito económico superior para el hechor.

\subsection{Caso N²: “Káiser y Donnkan”}

También en el contexto de un juicio oral simplificado, el 6 de agosto de 2011 el Juzgado de Garantía de Los Ángeles, Región del Biobío ${ }^{93}$, dicto sentencia condenatoria a través de la cual condenó a un individuo como autor del delito de maltrato o crueldad animal. Tal vez el aspecto más relevante del caso, tal como se detallará más adelante, consiste en que la defensa alegó como causal de justificación el estado de necesidad, pues sostuvo que los perros objeto del hecho atacaban a animales ganaderos de propiedad del imputado, obrando éste en su defensa.

\subsubsection{Imputación}

El Ministerio Público dedujo requerimiento en contra del encartado, R.H.V.C, fundándolo en que entre los días 4 y 7 de agosto de 2010, en el sector “Arrayán” de la ciudad de Los Ángeles, el requerido efectuó, con su escopeta, reiterados disparos en contra de los perros de nombre Káiser y Donnkan, raza pastor alemán, de uno y tres años de edad respectivamente, de "propiedad” de C.M.S.C., a consecuencia de lo cual los canes resultaron con múltiples laceraciones y fracturas, desangrándose en el lugar, resultando ambos muertos.

\subsubsection{Decisión}

El tribunal rechazó la causal de justificación invocada por la defensa del imputado, al no dar por acreditada la existencia del vacuno que habría sido atacado por los perros sacrificados, condenando al sujeto activo a sufrir la pena de 41 días de prisión, y a pagar una multa de 2 UTM (123€, aproximadamente).

\footnotetext{
${ }^{93}$ https://www.dropbox.com/s/14apft15log14tz/Sentencia\%202.pdf?dl=0
} 


\subsubsection{Análisis del caso}

Un primer aspecto importante de la sentencia en análisis consiste en la intervención del dueño del animal como víctima durante el procedimiento. Como se ha dicho, el ejercicio de tal potestad resulta improcedente, pues lo perseguido a través de la figura de maltrato o crueldad se aleja diametralmente del derecho de dominio o atributos que pueda poseer el tenedor del mismo.

Llama la atención, acto seguido, que el juez de la causa haya dedicado largos pasajes a justificar la razón que lo motiva a descartar la concurrencia del estado de necesidad invocado como causal de justificación por parte del imputado, centrando su análisis exclusivamente en la ausencia de acreditación del supuesto de hecho de la misma, sin percatarse que, atendido el bien jurídico protegido por la norma, y siendo susceptible de ser sacrificado por estado de necesidad sólo la propiedad ajena, la causal resultaba absolutamente inaplicable.

Un real aporte al tema objeto del presente estudio consiste en el concepto de crueldad que el juez desarrolla en el considerando $21^{\circ}$ del fallo. No habiéndose acreditado que los animales hayan sufrido con antelación a su muerte, el juez justifica la satisfacción de los requisitos objetivos del tipo afirmando que tal desenlace ocurrió de forma cruel, “entendiendo esta última expresión como, inhumanidad, fiereza de ánimo, impiedad”. Como se lee, el fallador centra el contenido de la expresión en un elemento interno y subjetivo del condenado.

Sin perjuicio de lo anterior, en el considerando $22^{\circ}$ el juez se aleja de la misma conclusión, formulando una proposición audaz, cuando señala que "matar a un animal, sin motivo aparente, será siempre un acto cruel, independiente de las circunstancias que lo rodeen, del mayor o menor sufrimiento que se cause previo al deceso, o de la disposición moral o subjetiva del hechor", pues "necesariamente hay que entender que matar a un animal sin motivo es un acto de inhumanidad, fiereza de ánimo o impiedad, es decir, un acto cruel, que merece el reproche penal”.

En resumen, si bien resulta criticable que se haya permitido la intervención procesal de la víctima y el nulo análisis respecto de la improcedencia del estado de necesidad como causal de justificación de la conducta, el esfuerzo argumentativo del juez a la hora de dotar de contenido a la expresión “crueldad” y de abordar la muerte del animal desligándola del sufrimiento, debe ser considerada como un notable aporte en la materia, aun cuando sus conclusiones puedan o no ser compartidas.

\subsection{Caso $N^{\circ} 3$ : "La arrastrada de Freirina”}

Ante el Juzgado de Garantía de Freirina, Región de Atacama, el 8 de septiembre de $2015^{94}$ se llevó a cabo procedimiento simplificado con admisión de responsabilidad, que concluyó en la condena de tres sujetos como autores del delito de crueldad o maltrato animal, en concurso real con otras figuras típicas.

\subsubsection{Imputación}

Los hechos objeto de la presente causa consisten en que el día 24 de octubre de 2014, aproximadamente a las 09:00 horas, tres imputados: J.M.C.C., J.A.L.S. y C.E.L.S., se desplazaban por la carreta más importante del país, denominada "Ruta 5”, en un camión, de cuyo costado colgaba, sujeto a una soga, un can de sexo femenino.

Esta situación fue observada por dos personas, a las que la sentencia considera

\footnotetext{
${ }^{94}$ https://www.dropbox.com/s/2h0ddsyghg7oe5h/Sentencia\%203.pdf?dl=0
} 
víctimas, quienes deciden devolverse en su vehículo y dar alcance al camión para solicitar que detuviera su marcha, cuestión que los imputados no hicieron y continuaron arrastrando al animal. Es así como las "víctimas" deciden cruzar su vehículo en el camino a fin de que los imputados se detuvieran.

Luego que lograran detenerlos, el conductor del camión, J.A.L.S, bajó del mismo manifestando a las "víctimas" que no se preocuparan pues solamente era un perro. En esas circunstancias, se produce una discusión donde el imputado antedicho procede a agredir a una de las "víctimas" ocasionándole lesiones, para posteriormente proferir amenazas contra todas ellas y lanzar piedras al vehículo en que se desplazaban.

5.3.2. Decisión

A través de la sentencia, cada uno de los imputados fue condenado como autor del delito consumado de maltrato animal a sufrir la pena de 61 días de presidio, y multa de 2 UTM (equivalente a $123 €$, aproximadamente), sin perjuicio de la responsabilidad en los delitos de lesiones, amenazas y daños.

\subsubsection{Análisis del caso}

Tratándose de un procedimiento auto-incriminatorio, la sentencia fue redactada de manera especialmente breve, limitándose a la descripción del hecho, su calificación jurídica, la determinación del grado de participación y ejecución del acto, y la expresión de la condena, sin que se haya explicitado el razonamiento del juez que determina su decisión.

No obstante ello, resulta destacable que el tribunal haya concluido la existencia de un concurso real de delitos, ordenando el cumplimiento sucesivo de las penas impuestas por los delitos de maltrato animal, lesiones menos graves, amenazas y daños simples, dando preeminencia a la sanción asignada al primero de los hechos, la que deberá ser cumplida antes que las demás, dejando en evidencia la valoración prevalente que el sentenciador hizo respecto del bien jurídico protegido por el delito de maltrato o crueldad por sobre los demás.

\subsection{Caso No4: “Spike”}

Luego de haberse desarrollado un juicio simplificado efectivo ante el Juzgado de Garantía de San Antonio, Región de Valparaíso, el 6 de diciembre de $2016^{95}$ se condenó a un imputado como autor del delito consumado de maltrato o crueldad animal en contra de un perro que se encontraba, a diferencia de los casos anteriores, bajo su propia tenencia.

\subsubsection{Imputación}

De acuerdo al requerimiento formulado por el ministerio Público, el día 15 de mayo de 2015, alrededor de las 21:30 horas, el imputado J.M.N.E. trasladó desde su domicilio hacia la vía pública a su perro de raza bóxer de nombre "Spike", de aproximadamente 13 años. Estando en la plaza ubicada en calle Las Palmeras esquina calle Isla de Pascua, comuna de San Antonio, el imputado procedió a golpear a dicho animal con una cadena metálica y posteriormente con un bloque de concreto, ocasionándole lesiones que, a juicio del persecutor, claramente le provocaron sufrimiento y posteriormente la muerte.

\subsubsection{Decisión}

La sentencia en análisis impone sólo una pena de multa de 2 UTM (123€, aproximadamente), concediendo, además, el plazo de dos meses para su pago.

\footnotetext{
${ }^{95}$ http://www.pjud.cl/documents/2538913/5582651/Maltrato+animal_fallo.pdf/1ee37ece-d547-4b6091d3-724297b61d47
} 


\subsubsection{Análisis del caso}

En el considerando $7^{\circ}$ de la sentencia, el fallador plantea su propia y creativa postura frente al objeto protegido por la figura típica en análisis, sosteniendo que "la finalidad última de este tipo penal, y de allí el bien jurídico protegido, es la de reprimir la extroversión de la perversión moral de un sujeto que satisface su malsano sentimiento de poder y de supremacía sobre otros seres vivos", reconociendo, acto seguido, que estos "otros seres vivos" poseen una "constitución psicológica y neurológica, de alguna manera muy similar a la del ser humano", cuyo daño o lesión sin sentido "repugna con los más elementales principios de respeto y compasión con el medio ambiente que nos rodea".

Se aprecia, aquí, que el juez sostiene una visión absolutamente antropocentrista del problema, postulando a la represión de la exteriorización de una especial perversión del autor como fin último del enunciado típico, exigiendo compasión con los animales debido a su similitud con el ser humano.

Por otro lado, tal como ha sostenido la doctrina, la referencia al "respeto y compasión con el medio ambiente" aparece como fuera de lugar pues, pese a que ciertas corrientes ubican a la protección animal en el contexto del cuidado del medio ambiente, "no parece que la tutela penal del medio ambiente tenga mucho que ver con la protección" que se le confiere a los animales domésticos ${ }^{96}$, como es el caso de "Spike".

Luego, en el considerando $9^{\circ}$ del fallo, se descarta la teoría de la defensa del imputado, quien alegaba que su conducta se motivó en la intensión de separar a Spike de otro perro con el que peleaba. El juez estima que las lesiones provocadas al perro dejan de manifiesto que "el bóxer claramente fue agredido en forma absolutamente cruel innecesaria e irracional”, no acogiendo la alegación antes señalada. Nótese aquí que se analiza por el órgano jurisdiccional la necesidad de la conducta lesiva, circunstancia que fue invocada como causal de justificación por el condenado.

Finalmente, llama la atención que se haya impuesto al condenado sólo una exigua pena de multa sin restricción alguna a su libertad personal, siendo discutible que tal determinación posea la aptitud necesaria para reafirmar la vigencia de la norma y satisfacer la expectativa colectiva de reacción penal.

\subsection{Caso Nº5: "Policial de la Plaza de Armas"}

El 27 de agosto de 2016, el Juzgado de Garantía de Punta Arenas, Región de Magallanes y la Antártica Chilena ${ }^{97}$, dictó sentencia condenatoria en contra del imputado H.E.G.H. atribuyéndole participación en calidad de autor en el delito consumado de maltrato o crueldad animal, en concurso real con amenazas con arma blanca. El presente caso reviste especial interés para la presente investigación, pues la defensa invocó como causal de exculpación el estado de necesidad, al no ser exigible otra conducta respecto del imputado quien habría visto amenazada su integridad física por el can.

\subsubsection{Imputación}

El día 13 de abril del año 2016, siendo aproximadamente las 19:20 horas, el imputado H.E.G.A. se encontraba en la Plaza de Armas "Muñoz Gamero" de esta ciudad, como así también se encontraban los jóvenes identificados como J.P.B.A., C.A.P.L., S.A.G.A.,

96 Ríos Corbacho, J. M. (2016). Nuevos tiempos para el delito de maltrato de animales a la luz de la reforma del Código Penal Español (LO 1/2015). Revista electrónica de ciencia penal y criminología, pag. 23

${ }^{97}$ https://www.dropbox.com/s/4um876lkv9myj67/Sentencia\%205.pdf?dl=0 
A.P.A.G, y J.M.C.S.M. Estos jóvenes solicitaron al imputado un cigarrillo, desatando en él una reacción injustificada, extrayendo un cuchillo entre sus vestimentas con el cuál apuntó al cuello a uno de estos jóvenes, específicamente de A.P.A.G. Luego, los adolescentes le pidieron al imputado que se calmara, logrando que guardara el cuchillo y se retirara del lugar, mientras seguía gritando insultos.

Acto seguido, un perro se acercó al imputado, con características similares a un perro policial, el que le ladró. H.E.G.A., en una reacción desmedida, extrajo nuevamente el cuchillo que portaba consigo y procedió a atacar al animal acuchillándolo en la plaza, en la zona de su abdomen, desangrándose y muriendo en ese lugar.

\subsubsection{Decisión}

En su decisión, el juez condena al imputado como autor del delito consumado de maltrato animal, e impone la pena de 100 días de presidio y multa de 2 UTM (123€, aproximadamente). Respecto de la pena corporal, la sustituye por reclusión nocturna en un recinto penitenciario.

\subsubsection{Análisis del caso}

En el considerando $9^{\circ}$ del fallo el juez descarta la configuración del estado de necesidad exculpante, pues estimó que los ladridos realizados por el can no eran aptos para ser considerados como un ataque, ni para haber puesto en riesgo a la persona del imputado. Luego, se reprocha al sujeto activo el no haber reaccionado de una manera diversa, pudiendo haber utilizado "desde una patada hasta arrancar y evitar el contacto".

Tal razonamiento aparece como correcto y especialmente relevante, pues, reconociendo que ciertos animales no humanos poseen aptitud para poner en riesgo la vida o la integridad física del ser humano, y habiendo previamente concluido que no resulta aplicable el estado de necesidad como causal de justificación, pues en el derecho chileno sólo puede sacrificarse bajo aquel pretexto la propiedad ajena, lo cierto es que la herramienta para evitar el reproche penal se encuentra en la exclusión de la culpabilidad, mediante la configuración de los requisitos del estado de necesidad exculpante establecido en el artículo 10 No11 del Código Penal, norma que exime de responsabilidad criminal a quien "obra para evitar un mal grave para su persona o derecho o los de un tercero, siempre que concurran las circunstancias siguientes: $1^{\mathrm{a}}$. Actualidad o inminencia del mal que se trata de evitar. $2^{\mathrm{a}}$. Que no exista otro medio practicable y menos perjudicial para evitarlo. $3^{\text {a }}$. Que el mal causado no sea sustancialmente superior al que se evita. $4^{\mathrm{a}}$. Que el sacrificio del bien amenazado por el mal no pueda ser razonablemente exigido al que lo aparta de sí o, en su caso, a aquel de quien se lo aparta siempre que ello estuviese o pudiese estar en conocimiento del que actúa”98.

\subsection{Caso No6: “Coco”}

El día 13 de enero de 2017, ante el Juzgado de Garantía de Viña del Mar, Región de Valparaíso ${ }^{99}$, se desarrolló audiencia en procedimiento simplificado, oportunidad en que el imputado E.L.C.F., luego de ser requerido por los hechos que se describirán a continuación, arribó a un acuerdo reparatorio con la víctima.

\subsubsection{Imputación}

El día 13 de diciembre de 2015, aproximadamente a las 20:50 horas, el imputado utilizando un arma, que bien puede ser de postones o de otro elemento que permita disparar

\footnotetext{
${ }^{98} \mathrm{https}: / / \mathrm{www}$.leychile.cl/Navegar?idNorma=1984

${ }_{99}$ https://www.dropbox.com/s/mcqvykp9k0ihk97/Acta\%206.doc?dl=0
} 
municiones, procedió a disparar en contra del gato de propiedad de I.A.A, llamado "Coco". A resulta de lo anterior, el animal resultó con paraplejia, sin movimiento de sus miembros posteriores. Los signos descritos fueron producidos por un proyectil tipo postón (trozo de plomo disparado con un arma de aire comprimido), el cual produjo una fractura en la columna del gato, produciendo una compresión y contusión de la medula espinal. Además, se aprecian esquirlas alojadas a nivel muscular.

\subsubsection{Decisión}

El acuerdo al que arribó el imputado y la "víctima” consistió en el pago de la suma total de \$1.250.000 (1.645€, aproximadamente), a ser pagada en cinco cuotas mensuales, iguales y sucesivas de $\$ 250.000$ cada una (328€, aproximadamente), además de asumir el imputado la obligación de pedir disculpas públicas.

\subsubsection{Análisis del caso}

De lo narrado, resulta completamente reprochable que el tribunal haya aprobado, como forma de término de la causa, un acuerdo reparatorio entre el imputado y la víctima, pues, conforme lo dispuesto en el artículo 241 inciso $2^{\circ}$ del Código Procesal Penal chileno, "los acuerdos reparatorios sólo podrán referirse a hechos investigados que afectaren bienes jurídicos disponibles de carácter patrimonial, consistieren en lesiones menos graves o constituyeren delitos culposos” ${ }^{100}$, situación dentro de las que, evidentemente, no se encuentra el maltrato animal.

Así, la conclusión alcanzada el tribunal en la causa en análisis constituye un franco retroceso en la evolución jurisprudencial que se evidenciaba en los fallos anteriores.

\section{CONCLUSIONES}

Finalizada la exposición del desarrollo histórico del ordenamiento jurídico chileno en materia de proscripción y castigo del maltrato animal, agotado el estudio de los alcances doctrinados que se derivan del tenor del enunciado típico que sanciona tal conducta, y analizados seis casos contemporáneos y relevantes sobre la materia, es posible concluir la presente investigación formulando las siguientes conclusiones:

Escasamente se ha identificado por la jurisprudencia al bienestar animal como el bien jurídico protegido por el delito de maltrato o crueldad, de lo que se deriva la casi total ausencia de consideración respecto de los requisitos o condiciones mínimas para su configuración, salvo el destacable razonamiento realizado en el primero de los casos estudiados.

De manera preponderante, la jurisprudencia ha otorgado a la figura típica objeto de esta investigación un contenido eminentemente patrimonial, lo que se concreta en el importante rol conferido a su dueño o tenedor, quien ha podido intervenir en ciertos casos como sujeto procesal, e incluso celebrar acuerdos reparatorios con el imputado.

Por otro lado, llama la atención la baja intensidad de la respuesta punitiva ordenada en la decisión judicial, asunto que, como hemos adelantado, permite presumir que la expectativa secundaria de reacción penal ante la ejecución de conductas típicas se ha visto mayormente defraudada.

Por lo anterior, y al no requerirse por el Ministerio Público la imposición de penas privativas de libertad superiores a los 541 días, no existen fallos relevantes dictados por Tribunales de Juicio Oral en lo Penal, órgano judicial del que generalmente emanan decisiones nutridamente fundamentadas, fruto de la deliberación de un tribunal colegiado.

\footnotetext{
${ }^{100}$ https://www.leychile.cl/Navegar?idNorma=176595
} 
Relacionado con la decisión contenida en las sentencias estudiadas, llama la atención la total ausencia de medidas de protección o reparación del daño sufrido por los animales no humanos cuando ellos han sobrevivido, herramienta contemplada en la ley ya desde 2009, pero que, al no haber sido incluida en el Código Penal, es frecuentemente desconocida por los operadores jurídicos.

Finalmente, la necesaria cautela del bienestar animal exige la imposición de medidas de seguridad respecto del hechor, a fin de disminuir el riesgo de reiteración de la conducta castigada, herramienta que recién se incorporó al ordenamiento jurídico nacional en agosto de 2017, cuando fue publicada la ley 21.020.

Como corolario de la presente investigación, se concluye que tanto la regulación normativa chilena como el razonamiento jurisprudencial doméstico en materia de protección animal, se encuentran a enorme distancia de los estándares internacionales y aquellos adoptados por países desarrollados, lo que no implica desconocer los avances registrados en la legislación recientemente aprobada, y en ciertos fallos donde se ha detectado adecuadamente la evolución moral sobre la materia.

\section{BIBLIOGRAFÍA}

- $\quad$ Bacigalupo, E. (1970). Conducta precedente y posición de garante. Problemas actuales de las Ciencias Penales y de la Filosofía del Derecho en homenaje a Jiménez de Asúa, 38.

- Cancio Meliá, M. (1993). La teoría de la adecuación social en Welzel. Anuario de derecho penal y ciencias penales, 697-730.

- Chahuán, S. (2012). Manual del nuevo procedimiento penal. Santiago de Chile: Thomson Reuters.

- Chible Villadangos, M. J. (2016). Introducción al Derecho Animal. Elementos y perspectivas. Revista ius et praxis, año 22, $N^{\circ} 2$, 373-414.

- De Carvalho González, E. (2016). La comisión por omisión en el delito de maltrato o crueldad animal. Santiago de Chile: Actividad formativa para optar al grado de Magister en Derecho por la Universidad de Chile.

- $\quad$ Duce, M., \& Riego, C. (2011). Proceso penal. Santiago de Chile: Editorial Jurídica de Chile.

- $\quad$ Escobar Gómez, S. (1997). De un predecesor árabe de Bentham en la defensa de los 'derechos de los animales". Anaquel de Estudios Árabes, Vol 8, 87-99.

- $\quad$ Eser, A. (2002). “La Adecuación social”: ¿ ¿Figura legal superflua o necesaria? Revista de derecho penal, Albert-Ludwigs-Universität Freiburg, 453-473.

- $\quad$ Etcheberry, A. (2005). Derecho penal, parte general, tomo II. Santiago de Chile: Editorial Jurídica de Chile.

- $\quad$ Garrido Montt, M. (2003). Derecho Penal, Tomo II. Santiago de Chile: Editorial Jurídica.

- $\quad$ Guzmán Dalbora, J. L. (2007). Estudios y defensas penales. Santiago de Chile: Lexis Nexis.

- $\quad$ Holmes, O. W. (1897). The Path of the Law. Harvard Law Review 457.

- Horvitz Lennon, M. I. (2007). Autoría y Participación en el delito imprudente . Revista de Estudios de la Justicia No70, 143-155.

- Horvitz, M. I., \& López, J. (2004). Derecho Procesal Penal Chileno. Santiago de Chile: Editorial Jurídica de Chile.

- $\quad$ Hughes, B. (1976). Preference decisions of domestic hens for wire or litter floors. Applied Animal Ethology 2, 155-165. 
- $\quad$ Jakobs, G. (1997). Derecho penal, parte general. Madrid: Marcial Pons.

- Kant, I. (2002). Lecciones de ética. Barcelona : Crítica.

- Kierszenbaum, M. (2009). El bien jurídico en el Derecho Penal, algunas nociones básicas desde la óptica de la discusión actual. Lecciones y Ensayos, $N^{\circ}$ 86, 187-211.

- $\quad$ Laimene Lelanchon, L. Leyes contra el maltato animal en Francia y España, en dA 5/1 (2014) http://revistes.uab.cat/da/article/view/v5-n1-laimene/112

- $\quad$ Liga Internacional de los Derechos del Animal. (1977). Declaración Universal de los Derechos del Animal.

- Maturana, C. (2012). Derecho procesal penal. Santiago de Chile: Thomson Reuters.

- $\quad$ Mir Puig, S. (2008). Derecho Penal, Parte General. Buenos Aires: BdeF.

- $\quad$ Real Academia Española. (2 de Julio de 2017). Diccionario de la lengua española. Obtenido de http://dle.rae.es

- Regan, T. (2007). Derechos animales y ética medioambiental. Studia Philosophica, 117-130.

- $\quad$ Ríos Corbacho, J. M. (2016). Nuevos tiempos para el delito de maltrato de animales a la luz de la reforma del Código Penal Español (LO 1/2015). Revista electrónica de ciencia penal y criminología, 1-55.

- $\quad$ Ríos Corbacho, J. M. (18 de 09 de 2017). LOS ANIMALES COMO POSIBLES SUJETOS DE DERECHO PENAL. Obtenido de Algunas referencias sobre los artículos 631 (suelta de animales feroces o dañinos) y 632 (malos tratos crueles) del Código Penal español:

https://www.unifr.ch/ddp1/derechopenal/articulos/a_20080526_86.pdf

- Rodríguez-Estévez, V. (2 de Julio de 2017). Zootecnia y gestión. Obtenido de Universidad de Córdoba:

http://www.uco.es/zootecniaygestion/img/pictorex/30_16_09_Binestar_Animal_VRE .pdf

- $\quad$ Roxin, C. (1997). Derecho Penal Parte General Tomo I. Madrid: Civitas.

- $\quad$ Singer, P. (1999). Liberación Animal. Madrid: Trotta.

- Vanda Cantón, B. (2 de Julio de 2017). EL SER HUMANO Y LOS ANIMALES. Obtenido de Universidad Nacional Autónoma de México : http://www.fmvz.unam.mx/fmvz/p_estudios/apuntes_bioet/Unidad_2_dolor.pdf

- $\quad$ Von Liszt, F. (2007). Tratado de derecho penal. Buenos Aires: Valletta.

- Welzel, H. (2011). Derecho penal alemán. Santiago de Chile: Editorial Jurídica de Chile.

- $\quad$ Zaffaroni, E. R. (2002). Deecho penal, parte general. Buenos Aires: Ediar. 